\title{
A transatlantic section at 14.5N: Meridional volume and heat fluxes
}

\author{
by Birgit Klein ${ }^{1,2}$, Robert L. Molinari ${ }^{3}$, Thomas J. Müller ${ }^{1}$ and Gerold Siedler ${ }^{1}$
}

\begin{abstract}
Two high-resolution hydrographic sections occupied during February, March 1989 in the western and eastern basins of the North Atlantic at $14.5 \mathrm{~N}$ are combined to study the water mass structure and meridional mass and heat transports. Absolute velocities were determined using these data and an earlier section at $8 \mathrm{~N}$ in a linear inverse analysis. Mass balance for several layers representing the main water masses in the region and a zero net divergence for the sum of geostrophic and Ekman transport between the two sections are assumed. Using the annual mean of Ekman transports $(13.6 \mathrm{~Sv}, 14.5 \mathrm{~N}),(15.2 \mathrm{~Sv}, 8 \mathrm{~N})$ based on the climatology by Isemer and Hasse (1985) the annual average fluxes for the sections at $8 \mathrm{~N}$ and $14.5 \mathrm{~N}$ have been calculated. For the annual mean the strength of the meridional overturning cell at $14.5 \mathrm{~N}$ amounts to $15.9 \mathrm{~Sv}$ with an associated heat transport of $1.22 \mathrm{PW}$. A similar value can be obtained at $8 \mathrm{~N}$ where the annual mean heat transport reaches $1.18 \mathrm{PW}$ and the overturning cell measures $15 \mathrm{~Sv}$. The total northward heat transport is strongly dominated by the wind-driven Ekman heat transport.

'In-situ' values of heat transport using the actual wind-driven transports for the respective months yield even higher estimates. Heat transport at $14.5 \mathrm{~N}$ rises to $1.37 \pm 0.42 \mathrm{PW}$ (February) and the maximum is now at the $8 \mathrm{~N}$ section, $1.69 \pm 0.52 \mathrm{PW}$ (May).

Comparisons of our results with another tropical section at $11 \mathrm{~N}$ occupied concurrently demonstrate the large variability in heat transport related to changes in the wind field. Due to extremely weak winds in the eastern Atlantic and a resulting low Ekman transport, the 'in-situ' value of heat transport through this section ranged between $0.30 \pm 0.18 \mathrm{PW}$ and $0.59 \pm$ $0.18 \mathrm{PW}$ depending on the value chosen for the Ekman transport. The lower of the two heat transport estimates results from calculations with the actual observed winds and the other using a monthly climatological mean. That even the computations with the climatological monthly mean give such a low heat transport points to additional changes in the baroclinic structures between $11 \mathrm{~N}$ and $14.5 \mathrm{~N}$.
\end{abstract}

\section{Introduction}

Transatlantic hydrographic sections were used in early oceanographic studies to provide a description of the large-scale water mass structure and circulation [e.g.

1. Institut für Meereskunde an der Universität Kiel, Kiel, Germany.

2. Universität Bremen, Institut für Umweltphysik, Abt. Tracer Ozeanographic, Kufsteiner Str., 28359 Bremen, Germany.

3. National Oceanic and Atmospheric Administration, Atlantic Oceanographic and Meteorological Laboratory, Miami, Florida, 93149, U.S.A. 
Wüst (1936), Defant (1936), Fuglister (1960), Warren (1973)]. In the tropical and subtropical North Atlantic several of these lines were established during the International Geophysical Year (1956/57) some of which have been reoccupied since then. Recent concern with the role of the ocean in forcing global climate change has focused attention on the ability of the ocean to transport heat. Data from transatlantic sections thus are now also used to study meridional heat flux by ocean currents (Bryden and Hall (1980); Roemmich (1983); Roemmich and Wunsch (1985), for instance). Many of the earlier heat flux cstimates wcre made at $24.5 \mathrm{~N}$ in the Atlantic where reliable measurements of the western boundary current offered an opportunity to determine the oceanic heat flux within small error limits and establish the annual cycle (Molinari et al., 1990). For low latitudes, however, very few estimates exist and very little is known from direct heat transport calculations about the annual variability.

A transatlantic section was occupied in the tropical North Atlantic Ocean along $14.5 \mathrm{~N}$. The transect, completed in February-March, 1989, was performed by two ships, the F.S. Meteor in the eastern Atlantic and R. V. Albatross in the western Atlantic. Although the location of the section was somewhat dictated by operational constraints, there is adequate scientific justification for its location. In particular, both modelling and observational studies indicate that oceanic heat flux has a maximum somewhere in the Atlantic tropics. The composition of the total heat flux can be expected to be somewhat different within this tropical band. At 14.5N, Ekman flux should make a larger contribution to heat flux than at $24.5 \mathrm{~N}$, for instance (Sarmiento, 1986).

The data from this section are therefore used to estimate meridional oceanic heat flux through $14.5 \mathrm{~N}$. We begin with a description of the available data. A brief description of transatlantic sections of temperature and salinity is given, followed by estimates of volume transport and heat flux. A discussion of the relation of the $14.5 \mathrm{~N}$ results to other studies completes the text.

\section{The data set}

In February 1989, the Marine Physics Department of the Institut für Meereskunde, University of Kiel, Germany and the Physical Oceanography Division of NOAA's Atlantic Oceanographic and Meteorological Laboratory, Miami, Florida joined in an observational program. A hydrographic section along $14.5 \mathrm{~N}$ was performed by two vessels. F.S. Meteor occupied the stations between the Mid-Atlantic Ridge (MAR) and the African coast (Fig. 1a.). Approximatley two weeks later R/V Albatross IV occupied the western part of the section between the MAR and the West Indies. The westernmost part of the Albatross section departed from a strictly zonal orientation (Fig. 1b). The change in orientation was necessary in order to complete the section at a continental slope and to approach this boundary perpendicularly.

At the western boundary, station spacing was about 30 nautical miles, with all casts 

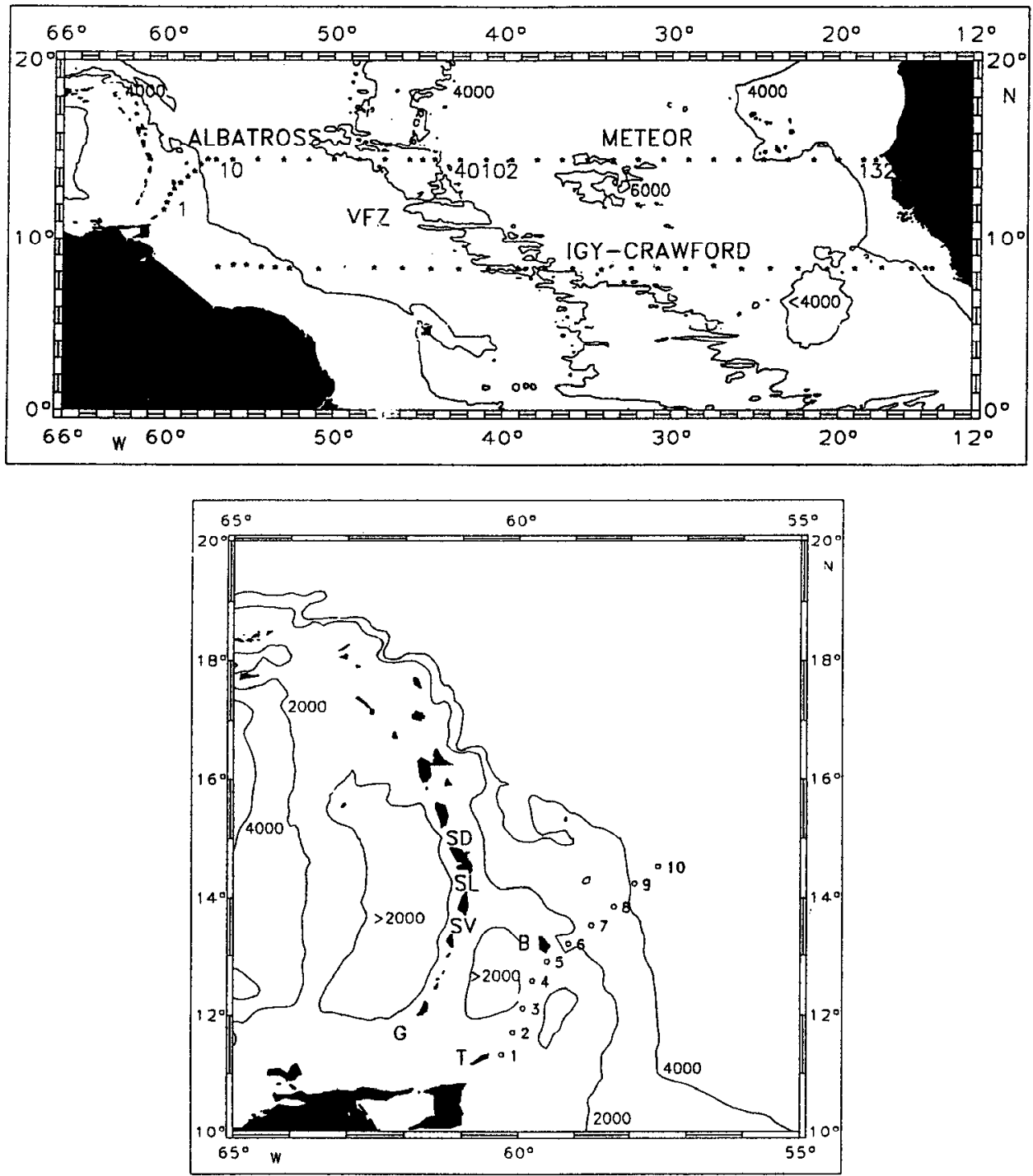

Figure 1. (a) Bottom topography in the tropical Atlantic Ocean. Station positions along the IGY section at $8 \mathrm{~N}$ and the 1989 section at $14.5 \mathrm{~N}$ are indicated by asterisks. Selected station labels are given for the $14.5 \mathrm{~N}$ section. The Vema Fracture Zone in the Mid-Atlantic Ridge is indicated by VFZ. (b) Bottom topography in the western tropical Atlantic near the Lesser Antilles. Station positions near the Lesser Antilles belonging to the section at $14.5 \mathrm{~N}$ are indicated by circles and labeled with station numbers. Passages through the Lesser Antilles discussed in the text are named G, SV, SL and SD for Grenada, St. Vincent, St. Lucia and St. Dominica Passage, respectively. Tobago and Barbados are labeled $\mathrm{T}$ and $\mathrm{B}$. 
Table 1. Station list. Asterisks mark stations reaching to the bottom

Profiles on section through western boundary current (Albatross)

\begin{tabular}{ccrr} 
Profile & Date & Time & \multicolumn{1}{c}{ Longitude } \\
01 & 14-FEB-1989 & $7: 43$ & $11^{\circ} 19.32^{\prime} \mathrm{N}$ \\
02 & 14-FEB-1989 & $12: 45$ & $11^{\circ} 42.30^{\prime} \mathrm{N}$ \\
03 & 14-FEB-1989 & $17: 18$ & $12^{\circ} 7.08^{\prime} \mathrm{N}$ \\
04 & 15-FEB-1989 & $21: 0$ & $12^{\circ} 34.20^{\prime} \mathrm{N}$ \\
05 & $15-$ FEB-1989 & $0: 34$ & $12^{\circ} 53.88^{\prime} \mathrm{N}$ \\
06 & $15-F E B-1989$ & $4: 19$ & $13^{\circ} 12.18^{\prime} \mathrm{N}$ \\
07 & $15-F E B-1989$ & $8: 20$ & $13^{\circ} 31.98^{\prime} \mathrm{N}$ \\
08 & 15-FEB-1989 & $12: 56$ & $13^{\circ} 51.00^{\prime} \mathrm{N}$ \\
09 & 15-FEB-1989 & $18: 09$ & $14^{\circ} 13.92^{\prime} \mathrm{N}$ \\
10 & $16-F E B-1989$ & $23: 32$ & $14^{\circ} 31.38^{\prime} \mathrm{N}$
\end{tabular}

Latitude

Profiles on $14.5 \mathrm{~N}$ section (Albatross)

Profile

Date

Time

Longitude

16-FEB-1989

7: 5

$14: 24$

16-FEB-1989

16-FEB- 1989

17-FEB-1989

$18: 27$

0: 6

17-FEB-1989

11:07

17-FEB-1989

17:58

18-FEB-1989

$21: 19$

18-FEB-1989

4:48

18-FEB-1989

$11: 42$

18-FEB-1989

14:45

19-FEB-1989

19-FEB-1989

21:22

5: 0

19-FEB-1989

19-FEB-1989

$7: 31$

13:47

20-FEB-1989

21: 0

20-FEB-1989

26

27

28

29

30

31

20-FEB-1989

23:57

7: 3

20-FEB-1989

13:36

20-FEB-1989

15:44

21-FEB-1989

22:13

21-FEB-1989

$4: 31$

21-FEB-1989

$6: 34$

21-HEB-1989

13: 5

22-FEB-1989

19:32

22-FEB-1989

1:55

22-FEB-1989

8:39

22-FEB-1989

22-FEB-1989

10:22

$16: 48$

23-FEB-1989

0.20

23-FEB-1989

1:12

$14^{\circ} 30.42^{\prime} \mathrm{N}$

$14^{\circ} 31.20^{\prime} \mathrm{N}$

$14^{\circ} 32.10^{\prime} \mathrm{N}$

$14^{\circ} 30.60^{\prime} \mathrm{N}$

$14^{\circ} 30.72^{\prime} \mathrm{N}$

$14^{\circ} 31.50^{\prime} \mathrm{N}$

$14^{\circ} 31.02^{\prime} \mathrm{N}$

$14^{\circ} 30.30^{\prime} \mathrm{N}$

$14^{\circ} 29.88^{\prime} \mathrm{N}$

$14^{\circ} 28.80^{\prime} \mathrm{N}$

$14^{\circ} 33.60^{\prime} \mathrm{N}$

$14^{\circ} 29.70^{\prime} \mathrm{N}$

$14^{\circ} 29.58^{\prime} \mathrm{N}$

$14^{\circ} 30.00^{\prime} \mathrm{N}$

$14^{\circ} 31.98^{\prime} \mathrm{N}$

$14^{\circ} 31.38^{\prime} \mathrm{N}$

$14^{\circ} 31.32^{\prime} \mathrm{N}$

$14^{\circ} 31.20^{\prime} \mathrm{N}$

$14^{\circ} 31.32^{\prime} \mathrm{N}$

$14^{\circ} 30.12^{\prime} \mathrm{N}$

$14^{\circ} 30.30^{\prime} \mathrm{N}$

$14^{\circ} 30.30^{\prime} \mathrm{N}$

$14^{\circ} 31.08^{\prime} \mathrm{N}$

$14^{\circ} 30.30^{\prime} \mathrm{N}$

$14^{\circ} 30.18^{\prime} \mathrm{N}$

$14^{\circ} 30.00^{\prime} \mathrm{N}$

$14^{\circ} 28.98^{\prime} \mathrm{N}$

$14^{\circ} 31.98^{\prime} \mathrm{N}$

$14^{\circ} 30.12^{\prime} \mathrm{N}$

$14^{\circ} 30.78^{\prime} \mathrm{N}$

$\begin{array}{ll}60^{\circ} 17.88^{\prime} \mathrm{W} & * \\ 60^{\circ} 6.12^{\prime} \mathrm{W} & * \\ 59^{\circ} 55.32^{\prime} \mathrm{W} & * \\ 59^{\circ} 45.30^{\prime} \mathrm{W} & * \\ 59^{\circ} 29.70^{\prime} \mathrm{W} & * \\ 59^{\circ} 6.90^{\prime} \mathrm{W} & * \\ 58^{\circ} 42.12^{\prime} \mathrm{W} & * \\ 58^{\circ} 17.88^{\prime} \mathrm{W} & * \\ 57^{\circ} 30.60^{\prime} \mathrm{W} & * \\ 57^{\circ} 30.60^{\prime} \mathrm{W} & *\end{array}$

Latitude

$\begin{array}{ll}57^{\circ} & 0.60^{\prime} \mathrm{W}\end{array}$

$56^{\circ} 33.12^{\prime} \mathrm{W}$

$56^{\circ} 33.60^{\prime} \mathrm{W}$

$56^{\circ} 1.50^{\prime} \mathrm{W}$

$55^{\circ} 14.82^{\prime} \mathrm{W}$

$54^{\circ} 32.28^{\prime} \mathrm{W}$

$54^{\circ} 33.90^{\prime} \mathrm{W}$

$53^{\circ} 44.52^{\prime} \mathrm{W}$

$53^{\circ} 0.90^{\prime} \mathrm{W}$

$53^{\circ} 2.82^{\prime} \mathrm{W}$

$52^{\circ} 18.18^{\prime} \mathrm{W}$

$51^{\circ} 31.02^{\prime} \mathrm{W}$

$51^{\circ} 30.48^{\prime} \mathrm{W}$

$50^{\circ} 46.20^{\prime} \mathrm{W}$

$50^{\circ} \quad 0.18^{\prime} \mathrm{W}$

$50^{\circ} \quad 0.78^{\prime} \mathrm{W}$

$49^{\circ} 16.62^{\prime} \mathrm{W}$

$48^{\circ} 30.72^{\prime} \mathrm{W}$

$48^{\circ} 31.62^{\prime} \mathrm{W}$

$47^{\circ} 45.00^{\prime} \mathrm{W}$

$46^{\circ} 59.52^{\prime} \mathrm{W}$

$47^{\circ} \quad 0.72^{\prime} \mathrm{W}$

$46^{\circ} 15.72^{\prime} \mathrm{W}$

$45^{\circ} 30.42^{\prime} \mathrm{W}$

$44^{\circ} 45.30^{\prime} \mathrm{W}$

$44^{\circ} \quad 0.72^{\prime} \mathrm{W}$

$44^{\circ} \quad 1.20^{\prime} \mathrm{W}$

$43^{\circ} 14.58^{\prime} \mathrm{W}$

$42^{\circ} 30.12^{\prime} \mathrm{W}$

$42^{\circ} 30.72^{\prime} \mathrm{W}$ 
Table 1. (Continued)

Profiles on $14.5 \mathrm{~N}$ section (Meteor)

\begin{tabular}{|c|c|c|c|c|}
\hline Profile & Datc & Time & Longitude & Latitude \\
\hline 98 & 5-FEB-1989 & $2: 5$ & $14^{\circ} 30.20^{\prime} \mathrm{N}$ & $44^{\circ} \quad 0.05^{\prime} \mathrm{W}$ \\
\hline 99 & 5-FEB-1989 & $9: 51$ & $14^{\circ} 30.10^{\prime} \mathrm{N}$ & $43^{\circ} 15.00^{\prime} \mathrm{W}$ \\
\hline 100 & 5-FEB-1989 & $15: 52$ & $14^{\circ} 29.90^{\prime} \mathrm{N}$ & $42^{\circ} 29.96^{\prime} \mathrm{W}$ \\
\hline 101 & 5-FEB-1989 & $22: 37$ & $14^{\circ} 30.00^{\prime} \mathrm{N}$ & $41^{\circ} 45.00^{\prime} \mathrm{W}$ \\
\hline 102 & 6-FEB-1989 & $6: 2$ & $14^{\circ} 30.07^{\prime} \mathrm{N}$ & $41^{\circ} \quad 0.02^{\prime} \mathrm{W}$ \\
\hline 103 & 6-FEB-1989 & $13: 18$ & $14^{\circ} 30.05^{\prime} \mathrm{N}$ & $40^{\circ} 14.84^{\prime} \mathrm{W}$ \\
\hline 104 & 6-FEB-1989 & $19: 11$ & $14^{\circ} 29.94^{\prime} \mathrm{N}$ & $39^{\circ} 30.02^{\prime} \mathrm{W}$ \\
\hline 105 & 7-FEB-1989 & $3: 40$ & $14^{\circ} 30.06^{\prime} \mathrm{N}$ & $38^{\circ} 44.90^{\prime} \mathrm{W}$ \\
\hline 106 & 7-FEB-1989 & $9: 46$ & $14^{\circ} 30.01^{\prime} \mathrm{N}$ & $38^{\circ} 0.01^{\prime} \mathrm{W}$ \\
\hline 107 & 7-FEB-1989 & $17: 24$ & $14^{\circ} 30.02^{\prime} \mathrm{N}$ & $37^{\circ} 15.12^{\prime} \mathrm{W}$ \\
\hline 108 & 8-FEB-1989 & $0: 40$ & $14^{\circ} 30.00^{\prime} \mathrm{N}$ & $36^{\circ} 30.10^{\prime} \mathrm{W}$ \\
\hline 109 & 8-FEB-1989 & $8: 40$ & $14^{\circ} 30.05^{\prime} \mathrm{N}$ & $35^{\circ} 45.02^{\prime} \mathrm{W}$ \\
\hline 110 & 8-FEB-1989 & $14: 55$ & $14^{\circ} 30.00^{\prime} \mathrm{N}$ & $34^{\circ} 59.99^{\prime} \mathrm{W}$ \\
\hline 111 & 9-FEB-1989 & $0: 16$ & $14^{\circ} 30.00^{\prime} \mathrm{N}$ & $34^{\circ} 15.10^{\prime} \mathrm{W}$ \\
\hline 112 & 9-FEB-1989 & $6: 46$ & $14^{\circ} 29.95^{\prime} \mathrm{N}$ & $33^{\circ} 30.10^{\prime} \mathrm{W}$ \\
\hline 113 & 9-FEB-1989 & $14: 41$ & $14^{\circ} 30.05^{\prime} \mathrm{N}$ & $32^{\circ} 44.87^{\prime} \mathrm{W}$ \\
\hline 114 & 9-FEB-1989 & $22: 1$ & $14^{\circ} 30.10^{\prime} \mathrm{N}$ & $32^{\circ} 0.00^{\prime} \mathrm{W}$ \\
\hline 115 & 10-FEB-1989 & $5: 34$ & $14^{\circ} 29.98^{\prime} \mathrm{N}$ & $31^{\circ} 15.05^{\prime} \mathrm{W}$ \\
\hline 116 & 10-FEB-1989 & $11: 56$ & $14^{\circ} 29.99^{\prime} \mathrm{N}$ & $30^{\circ} 29.99^{\prime} \mathrm{W}$ \\
\hline 117 & 10-FEB-1989 & $19: 44$ & $14^{\circ} 29.98^{\prime} \mathrm{N}$ & $29^{\circ} 45.04^{\prime} \mathrm{W}$ \\
\hline 118 & 11-FEB-1989 & 3: 1 & $14^{\circ} 30.07^{\prime} \mathrm{N}$ & $29^{\circ} 0.00^{\circ} \mathrm{W}$ \\
\hline 119 & 11-FEB-1989 & $10: 41$ & $14^{\circ} 30.00^{\prime} \mathrm{N}$ & $28^{\circ} 14.90^{\prime} \mathrm{W}$ \\
\hline 120 & 11-FEB-1989 & $16: 44$ & $14^{\circ} 30.08^{\prime} \mathrm{N}$ & $27^{\circ} 29.96^{\prime} \mathrm{W}$ \\
\hline 121 & 12-ГСВ-1989 & $1: 20$ & $14^{\circ} 30.11^{\prime} \mathrm{N}$ & $26^{\circ} 44.93^{\prime} \mathrm{W}$ \\
\hline 122 & 12-FEB-1989 & $7: 57$ & $14^{\circ} 29.96^{\prime} \mathrm{N}$ & $26^{\circ} \quad 0.02^{\prime} \mathrm{W}$ \\
\hline 123 & 12-FEB-1989 & $15: 44$ & $14^{\circ} 30.00^{\prime} \mathrm{N}$ & $25^{\circ} 14.91^{\prime} \mathrm{W}$ \\
\hline 124 & 12-FEB-1989 & $22: 39$ & $14^{\circ} 30.10^{\prime} \mathrm{N}$ & $24^{\circ} 30.00^{\prime} \mathrm{W}$ \\
\hline 125 & 13-FEB-1989 & $5: 20$ & $14^{\circ} 29.99^{\prime} \mathrm{N}$ & $23^{\circ} 44.73^{\prime} \mathrm{W}$ \\
\hline 126 & 13-FEB-1989 & $12: 8$ & $14^{\circ} 30.19^{\prime} \mathrm{N}$ & $22^{\circ} 59.93^{\prime} \mathrm{W}$ \\
\hline 127 & 13-FEB-1989 & $18: 46$ & $14^{\circ} 29.94^{\prime} \mathrm{N}$ & $22^{\circ} 15.01^{\prime} \mathrm{W}$ \\
\hline 128 & 14-FEB-1989 & $0: 44$ & $14^{\circ} 30.13^{\prime} \mathrm{N}$ & $21^{\circ} 29.89^{\prime} \mathrm{W}$ \\
\hline 129 & 14-FEB-1989 & $7: 20$ & $14^{\circ} 30.06^{\prime} \mathrm{N}$ & $20^{\circ} 44.98^{\prime} \mathrm{W}$ \\
\hline 130 & 14-FEB-1989 & 13: 4 & $14^{\circ} 30.20^{\prime} \mathrm{N}$ & $19^{\circ} 59.86^{\prime} \mathrm{W}$ \\
\hline 131 & 14-FEB-1989 & $20: 30$ & $14^{\circ} 30.10^{\prime} \mathrm{N}$ & $19^{\circ} 14.90^{\prime} \mathrm{W}$ \\
\hline 132 & 15-FEB-1989 & 2: 0 & $14^{\circ} 30.24^{\prime} \mathrm{N}$ & $18^{\circ} 29.91^{\prime} \mathrm{W}$ \\
\hline 133 & 15-FEB-1989 & $8: 6$ & $14^{\circ} 30.20^{\prime} \mathrm{N}$ & $17^{\circ} 45.90^{\prime} \mathrm{W}$ \\
\hline
\end{tabular}

taken to the bottom. Along $14.5 \mathrm{~N}$, station spacing was 45 nautical miles. Cast depths alternated between the ocean bottom and $2000 \mathrm{~m}$. At the MAR, three stations overlapped, with a time separation of 19 days. Station positions and times are summarized in Table 1.

Processing of the Albatross and Meteor CTD data has been described in Wilburn et 
al. (1990) and Klein (1992), respectively. Laboratory calibrations of the Albatross temperature and pressure CTD sensors indicated accuracies of $\pm 2 \mathrm{mK}$ and $\pm 3 \mathrm{dbar}$. A post-cruise laboratory calibration of the Meteor sensors revealed the same uncertainties.

Water samples were used on both ships to calibrate the CTD conductivity sensors. Comparison of calibrated deep Meteor potential temperature-salinity (hereafter TS) values with historical northeast Atlantic values (Saunders, 1986) and overlapping calibrated Albatross station values indicated that the Meteor salinity values were 0.003-0.004 psu lower. These differences are attributed to differences in standard seawater batches (Mantyla, 1987). A constant salinity correction of +0.003 psu was added to the Meteor data to make the data-sets compatible (Fig. 2). The accuracy of the final data set is \pm 0.002 psu.

\section{Water masses and vertical sections}

The deeper water masses observed on the Albatross section have been described in Molinari et al. (1992). Water masses within the eastern basin have been described in Klein (1992). Therefore, herein, we will only briefly review these earlier findings. Figure 3 presents the zonally averaged temperature/salinity relationship for the $14.5 \mathrm{~N}$ section. For each station the salinity was calculated as a function of potential temperature subdivided into $0.1^{\circ} \mathrm{C}$ classes and finally averaged over the whole section.

Proceeding from the upper portion of the water column, the first extremum in TS properties at about $22^{\circ} \mathrm{C}$ is associated with the salinity maximum characteristic of Subtropical Underwater (SUW), also called Subtropical Salinity Maximum Water. This water mass is formed in the eastern subtropical Atlantic, where evaporation exceeds precipitation (Defant, 1936; Worthington, 1976). At $14.5 \mathrm{~N}$ the SUW is divided into two salinity maxima one of North and one of South Atlantic origin. The straight line portion of the TS curve between about 8 and $20^{\circ} \mathrm{C}$ represents both North and South Atlantic Central Water. The former is saltier and found in the western part of the section and the latter in the east. The Central Water is bounded below by the salinity minimum of Antarctic Intermediate Water (AAIW) at about $6^{\circ} \mathrm{C}$. Proceeding deeper, the salinity maximum characteristic of the various components of North Atlantic Deep Water (NADW) is bounded below by mixtures of Antarctic Bottom Water (AABW) and NADW (Worthington, 1976). There is a large scatter (not shown in this figure) about the mean TS curve at all potential temperatures indicative of the variability of the water mass characteristics along the section. The variability will be discussed in more detail shortly.

Vertical sections of potential temperature, salinity and salinity anomaly from the Albatross section were described in Molinari et al. (1992). Similarly, Meteor sections for potential temperature and salinity were discussed in Klein (1992). Herein, 


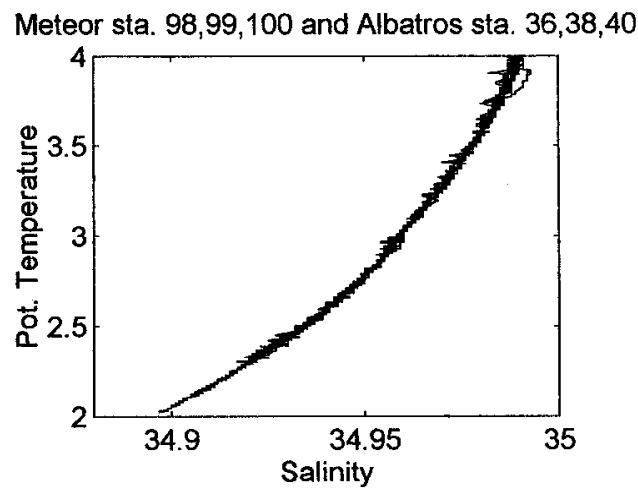

Figure 2. Potential temperature and salinity diagram for Albatross and Meteor stations overlapping at the Mid-Atlantic Ridge. An offset of 0.003 psu was added to the Meteor profile to achieve the match for both profiles in the deep water as shown here.

transallantic sections of potential temperature, salinity, density and salinity anomaly are described (Fig. 4a-d). Density is given as potential density referenced to the surface for values above $27.88 \mathrm{~kg} / \mathrm{m}^{3}$ and to $4000 \mathrm{dbar}$ below. The salinity anomaly is defined as the difference between the observed salinity and the zonally averaged salinity at the same potential temperature, as given in Figure 3.

The potential temperature section (Fig. 4a) shows a deepening of the upper thermocline depth from east to west. In fact, isotherms within the thermocline in the west intersect the sea surface in the east. Below about $3000 \mathrm{~m}$, the isotherms become discontinuous across the MAR. Much lower temperatures are observed west of the MAR.

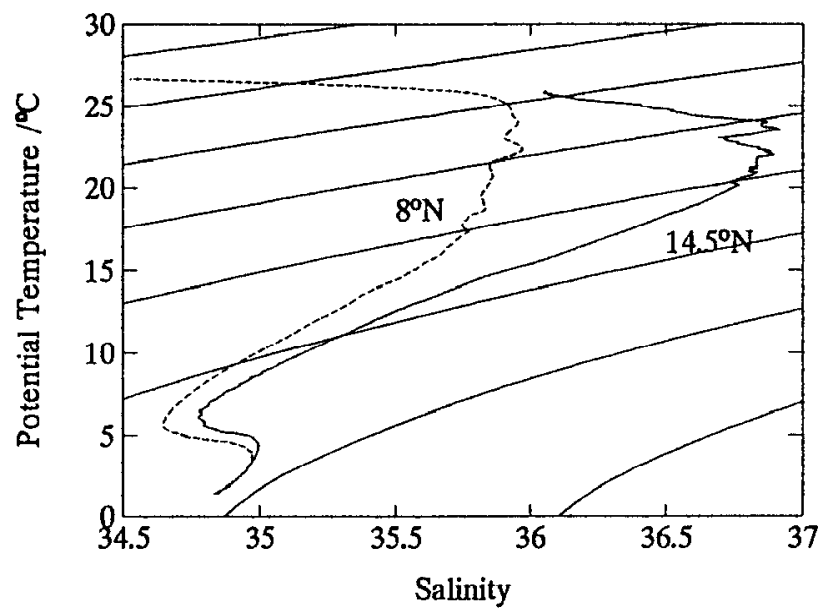

Figure 3. Zonally averaged temperature/salinity curves for the sections at 8 and $14.5 \mathrm{~N}$. 

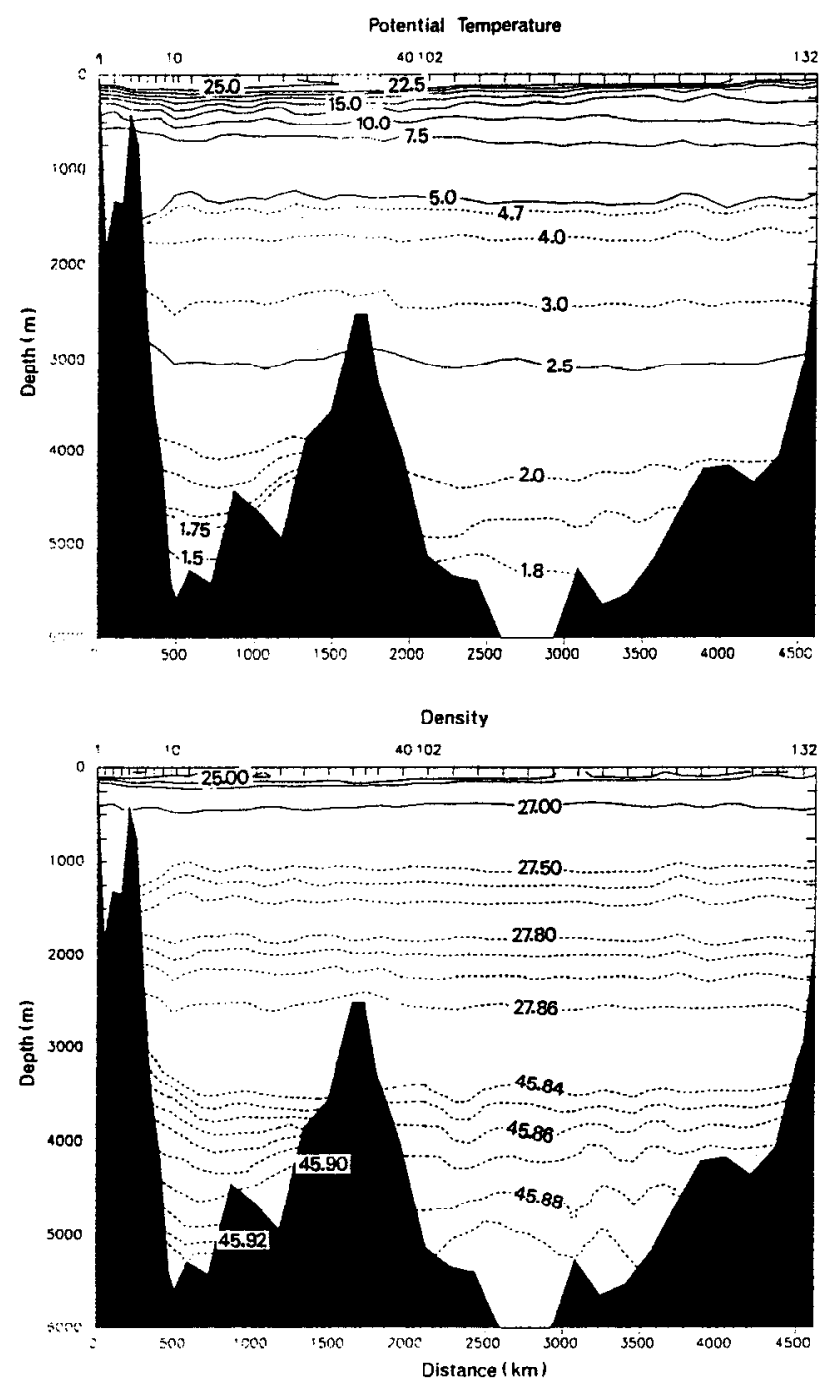

Figure 4. Vertical sections at $14.5 \mathrm{~N}$ of potential temperature (a), salinity (b), potential density (c) and salinity anomaly (d) (see text) in psu multiplied by 1000 . Only stations reaching to the bottom have been used for this figure. These stations are marked by asterisks in Table 1 .

The salinity sections display the distinct extrema described above. In the upper thermocline, the subsurface salinity maximum of SUW reaches values above $37.2 \mathrm{psu}$ near the western boundary (Fig. 4b). This salinity maximum is subducted and carried away from its source region within the anticyclonic subtropical gyre (Defant, 1936; Bauer and Siedler, 1988). At 14.5N it extends well across the MAR, but is not observed on the easternmost stations.

Below the SUW, salinity decreases to a minimum value at about $750 \mathrm{~m}$ (i.e., 

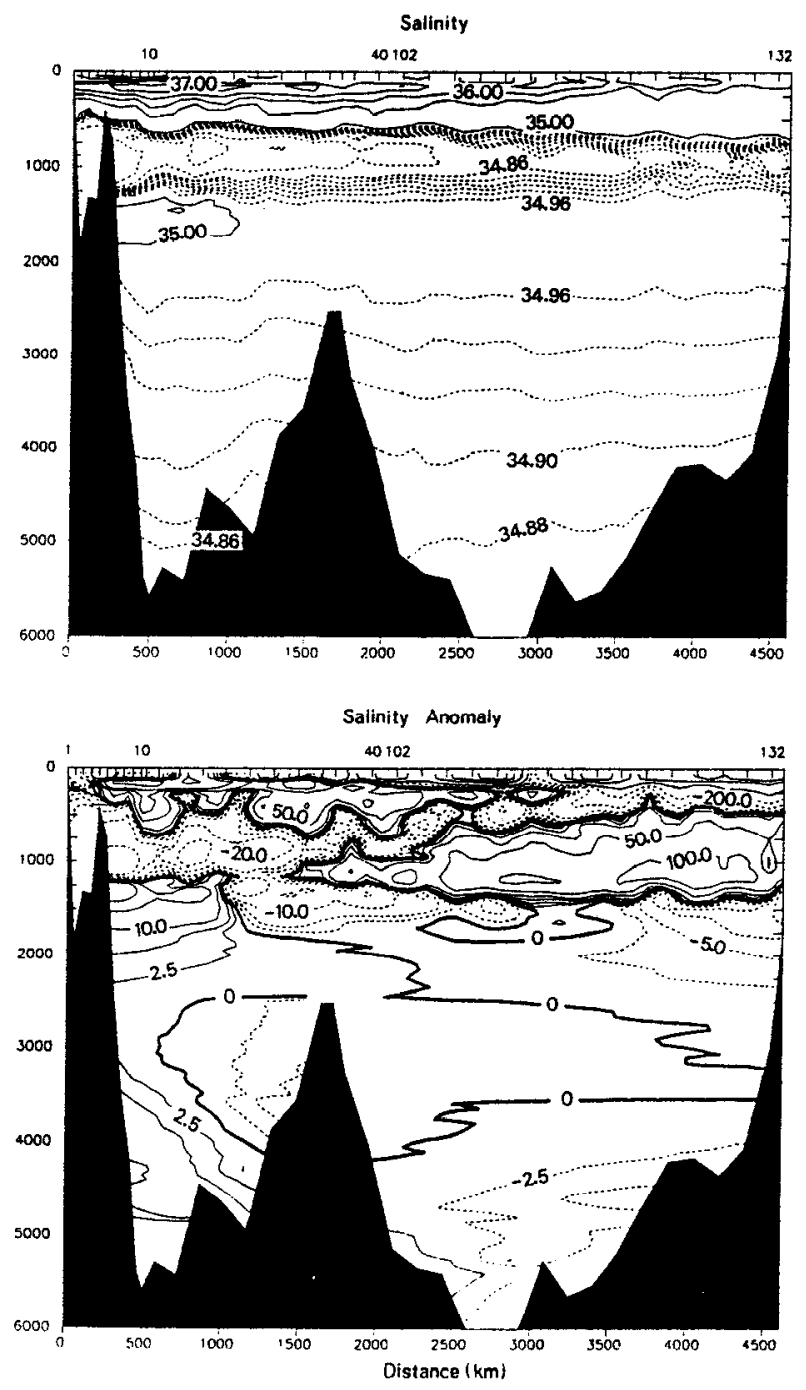

Figure 4. (Continued)

AAIW). Lowest AAIW salinities are observed on the extreme western side of the section. Below the AAIW salinities increase again within the depth range of NADW. This water mass is traditionally subdivided into three layers (Wüst, 1936). In the upper NADW, contributions from Mediterranean Water can be identified by the salinity maximum between 1400 and $1800 \mathrm{~m}$ in the west. This core appears in the salinity anomaly plot as well as the salinity section (Fig. 4d,b).

Close to the western boundary, the high salinity anomaly core is coincident with a chlorofluorocarbon (CFC) core (Molinari et al., 1992). Pickart (1992), using CFC data, determined the formation region to be inshore of the North Atlantic Current 
and south of the formation region of traditional Labrador Sea Water. This water is transported south under the Gulf Stream, where it is mixed with warmer and saltier water on the offshore edge of the DWBC, thus obtaining a higher salinity signal. The core of higher salinity anomaly at $1500 \mathrm{~m}$ is separated by a layer of lower anomaly from a deeper high salinity core between $3250 \mathrm{~m}$ and $4500 \mathrm{~m}$ (Fig. 4d). This lower core, also coincident with a high CFC core (Molinari et al., 1992) originates through mixing of Denmark Strait Overflow Water and other sources of deep water formation.

The two high salinity and CFC cores of DWBC are continuous features of the water mass distribution between $26 \mathrm{~N}$ and 13N, (Fine and Molinari, 1988). Jenkins and Rhines (1980) observed two cores with high tritium concentrations at nearly the same levels as the salinity and CFC cores. They considered the minimum tritium water between the cores to be generated by entrainment of water masses from the subtropical ocean.

Below $3000 \mathrm{~m}$, salinity as well as temperature is discontinuous across the MAR (Figs. 4a and 4b). Lowest bottom salinities and temperatures are observed in the western basin. The MAR is acting as a barrier to the coldest and freshest Antarctic Bottom Water (AABW) in this depth range. A supply of AABW into the eastern Atlantic is provided through the Romanche Fracture Zone near the Equator and the Vema Fracture Zone at 11N (Wüst, 1936; McCartney et al., 1991). Only diluted forms of $A A B W$ reach the eastern basin because of mixing with overlying water in the fracture zones.

The influence of AABW in the eastern basin and its various pathways have been studied by McCartney et al. (1991). From their study it is evident that northward of the Equator to approximately $8 \mathrm{~N}$ the eastern basin is influenced by AABW which entered through the Romanche Fracture Zone at the Equator and is warmed considerably through mixing on its way north. A second tongue of colder AABW that enters the eastern basin through the Vema Fracture Zone at $11 \mathrm{~N}$ is also visible in their study. However, its northern extent and strength could not be properly resolved with the available data set since the next section to the north was situated at $16 \mathrm{~N}$. No bottom water with temperatures less than $1.8^{\circ} \mathrm{C}$ was found along this section.

Lowest bottom salinities and temperatures in the eastern and western basins are listed in Table 2 for sections at $16 \mathrm{~N}, 14.5 \mathrm{~N}$ and $8 \mathrm{~N}$. The two sections at $8 \mathrm{~N}$ and $16 \mathrm{~N}$ have been sampled during the IGY program in 1956/57. The inflow of colder and fresher AABW through the Vema Fracture Zone into the eastern basin is evident from the fact that temperatures and salinities are significantly lower at $14.5 \mathrm{~N}$ than to the north and south. At $14.5 \mathrm{~N}$, AABW has filled the deepest part of the eastern basin with the lowest potential temperatures less than $1.75^{\circ} \mathrm{C}$ (Table 2). Compared to the densest water observed at the outflow of the Vema Fracture Zone, with a potential temperature of $1.66^{\circ} \mathrm{C}$, (McCartney et al., 1991) there is surprisingly littlc cvidence for further mixing. 
Table 2. Bottom values of potential temperature $\theta$ and salinity $S$ in the western and eastern basin along three sections in the tropics. Sections at $8 \mathrm{~N}$ and $16 \mathrm{~N}$ have been collected during the IGY-program 1956/57.

\begin{tabular}{|c|c|c|}
\hline Section & Western Basin & Eastern Basin \\
\hline $08.0 \mathrm{~N}$ & $1.300,34.840$ & $1.842,34.881$ \\
\hline $14.5 \mathrm{~N}$ & $1.360,34.829$ & $1.748,34.868$ \\
\hline $16.0 \mathrm{~N}$ & $1.386,34.839$ & $1.824,34.880$ \\
\hline
\end{tabular}

\section{Geostrophic velocities and transports}

In order to compute a thermodynamically rigorous heat flux estimate from a single transect, the net mass transport through the section must be zero; i.e., the total integrated geostrophic transport has to balance the net Ekman transport. In order to evaluate the climatic relevance of a heat flux estimate from an isolated section, the long-term representativeness of various components must be considered. This applies particularly to the surface wind stress which has a large annual signal in the tropics (Isemer and Hasse, 1885). Monthly estimates of Ekman transport will therefore differ considerably from the annual mean and will not be representative of the annual average. During the first 3 months of 1989 the actual wind data even showed larger than seasonal amplitude variations. This variability will be discussed in detail in Section 7 in comparison with another heat transport section at $11 \mathrm{~N}$. We will present calculations using either mean monthly or annual mean winds, and for comparison purposes in-situ winds. These estimates will be used in combination with the geostrophic signal to calculate the heat flux through the sections. Böning and Hermann (1994) provide modelling results that suggest that the annual signal of the geostrophic overturning circulation is very small in the tropics and subtropics, i.e., an isolatcd scction can provide a represcntative cstimatc of the mean annual heat flux due to meridional overturning.

The Isemer and Hasse (1985) wind stress climatology was used in our computations to estimate the Ekman transports. Using the mean monthly February wind stresses, the Ekman transport through the $14.5 \mathrm{~N}$ section is $15.9 \mathrm{~Sv}$. Using the mean annual wind stress, the Ekman transport is $13.6 \mathrm{~Sv}$. The actual winds measured along $14.5 \mathrm{~N}$ in February 1989 by the shipboard sensors amounted to an Ekman transport of 19.3 Sv which is somewhat higher than the climatological mean but comparable within error bars. One reason for using the climatological values instead of the instantaneous ones is that the $14.5 \mathrm{~N}$ section will be compared to a section at $8 \mathrm{~N}$ for which no concurrent wind measurements were available.

In the simplest geostrophic calculation, a level of zero velocity at the depth of the $4.7^{\circ} \mathrm{C}$ isotherm was selected following Molinari et al. (1992). In cases were the $4.7^{\circ} \mathrm{C}$ 
isotherm was not encountered within the depth range of the profiles the bottom was selected as reference level. This isotherm, found at a depth of about $1400 \mathrm{~m}$, was chosen as it represents the approximate boundary between $\Lambda \Lambda I W$ and NADW and it can be expected that on long time scales the two water masses flow in opposite directions. The total geostrophic transport was $10.5 \mathrm{~Sv}$ to the south resulting in a net transport imbalance of 5.5 Sv with respect to the February Ekman transport. To the lowest order, a zero mass balance could be obtained for the $14.5 \mathrm{~N}$ section by applying a uniform barotropic velocity to the whole section with a magnitude of $-0.064 \mathrm{~cm} / \mathrm{s}$ (positive values indicate northward velocities). However, such an approximation ignores any possible longitudinal dependence for the barotropic component of the flow through the section. Thus, a linear inverse analysis was employed to estimate the barotropic velocity field.

To apply the analysis at least two coast-to-coast sections are required. Geostrophy, mass conservation, and a zero velocity level at the depth of the $4.7^{\circ} \mathrm{C}$ isotherm are assumed. As second transect an IGY-section at $8 \mathrm{~N}$ is used. This section was occupied during May 1957 and the assumption of long term stationarity and small annual signal throughout the water column were therefore required. As discussed above the model results of Böning and Hermann (1994) support the second assumption, the first will now be discussed.

As for the $14.5 \mathrm{~N}$ section, a lowest order mass balance calculation was performed for the $8 \mathrm{~N}$ section applying a uniform barotropic velocity to balance either the annual mean Ekman volume transport (15.2 Sv) or a monthly mean for May (21.2 Sv). With a time spacing of more than 30 years between the two sections changes in the baroclinic structure due to variability in the production rate of deep and bottom waters cannot be discarded a priori and the decadal variability has to be examined before the two sections can be combined in the inverse analysis. A comparison of layer transports from the lowest order mass balance calculations showed similar structures and comparable magnitude of transports, thus gave no indication of major changes in the baroclinic structure. Imbalances in transports between the two sections are probably due to the assumption of a uniform barotropic reference velocity for the entire section. This compares to the results by Roemmich and Wunsch (1985) who analyzed sections at $24 \mathrm{~N}$ and $36 \mathrm{~N}$ and obtained better transport balances using the inverse technique to determine the reference velocities.

Calculations of volume and heat transport estimates using a monthly mean Ekman transport should be viewed as representing a seasonal view of the fluxes. May as well as February fall into the season of maximum wind-driven transport which has a peak between December and May (Fig. 5). Over the entire period of high Ekman transport very little variation is observed and amplitudes differ by less than $2.5 \mathrm{~Sv}$ over the whole time range. For the seasonal view we therefore chose the climatological mean of the respective month instead of a seasonal mean assuming that they are comparable within error bars. While the spring maximum is rather broad the 
Ekman volume transport at $8 \mathrm{~N}(0)$ and $14.5 \mathrm{~N}\left({ }^{*}\right)$

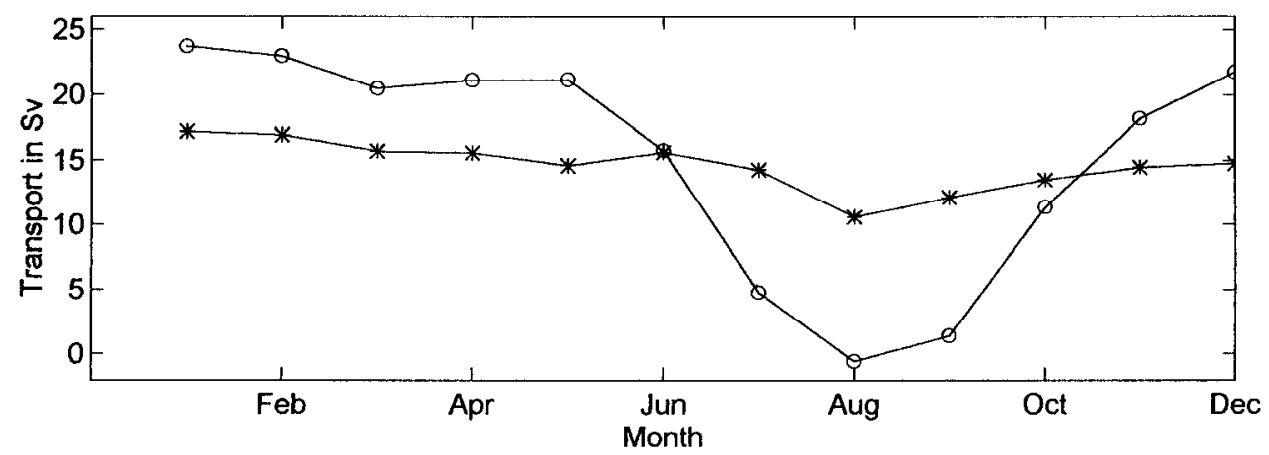

Figure 5. Seasonal variation of Ekman transport at 8 and 14.5N.

minimum in August is very sharp and Ekman volume transports can vary by more than $5 \mathrm{~Sv}$ between consecutive months within this season.

A detailed description of the flow field and associated layer transports will only be given for the seasonal case since the annual mean has very similar structures. In the inverse analysis, for each of the layers listed in Table 3, mass conservation is required for the box formed by the two sections. As an additional constraint, the Ekman transport must exactly balance the geostrophic transport. The solution of the underdetermined linear equation system is found by singular value decomposition. The results of this analysis are station-dependent barotropic corrections which are displayed in Figure 6 for the seasonal case.

Absolute velocity transects for the seasonal case are given in Figures 7 and 8 . In both sections enhanced shallow northward transport is found at the western boundary, at depths less than $1000 \mathrm{~m}$ and at the shelf break, with a southward flow separating the two branches. It is somewhat difficult to define the boundary current transport in this region where it is not confined by topography like in the Straits of

Table 3. Water masses and their isopycnic boundaries.

\begin{tabular}{|c|l|l|}
\hline Layer no. & Upper and lower interface & Water mass \\
\hline 1 & Ocean surface to $\sigma_{\theta}=26.028$ & Surface waters \\
\hline 2 & $\sigma_{\theta}=26.028$ to $\sigma_{\theta}=27.187$ & NACW $/$ SACW \\
\hline 3 & $\sigma_{\theta}=27.187$ to $\sigma_{2}=36.701$ & AAIW \\
\hline 4 & $\sigma_{2}=36.701$ to $\sigma_{2}=36.980$ & upper NADW \\
\hline 5 & $\sigma_{2}=36.980$ to $\sigma_{4}=45.840$ & middle NADW \\
\hline 6 & $\sigma_{4}=45.840$ to $\sigma_{4}=45.900$ & lower NADW \\
\hline 7 & $\sigma_{4}=45.900$ to bottom & AABW \\
\hline
\end{tabular}



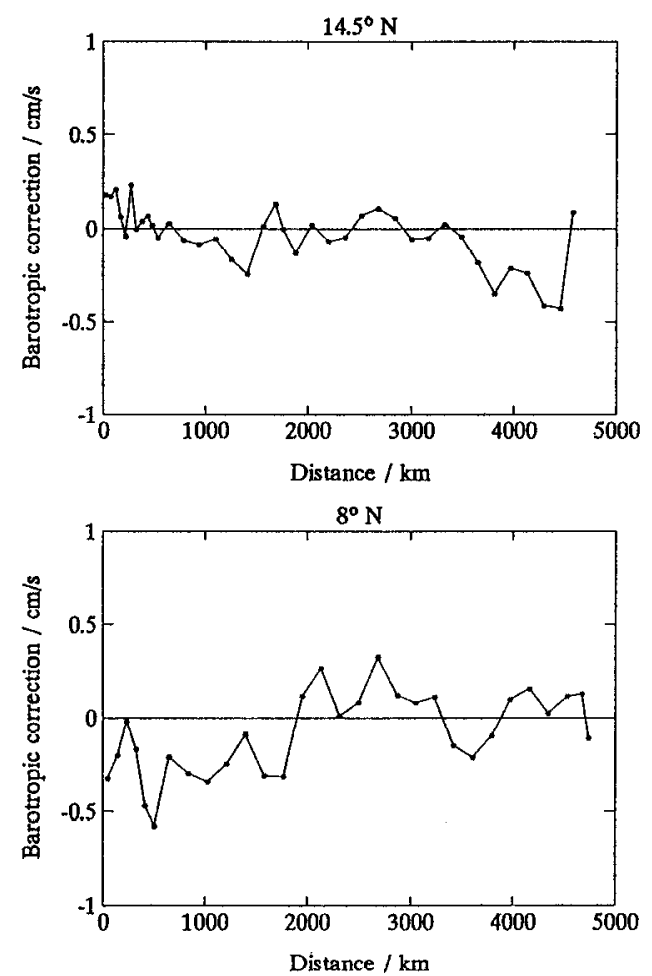

Figure 6. Barotropic velocity corrections from the inverse calculation for the sections at $8 \mathrm{~N}$ and $14.5 \mathrm{~N}$. Calculations have been performed using a monthly mean Ekman transport.

Florida. The upper limit of boundary current transport is obtained by taking the transport in the two northward bands and ignoring the southward counterflow. Maximum northward transport as defined above amounts to $23 \mathrm{~Sv}$ at $8 \mathrm{~N}$ and $24 \mathrm{~Sv}$ at $14.5 \mathrm{~N}$ (see schematic in Fig. 10) and is partitioned into nearly equal amounts between the branches over the shelf and the shelf break (Fig. 7 and 8). It is reduced by about $6 \mathrm{~Sv}$ at both latitudes if the counterflow is taken into account.

The deep western boundary current (DWBC) can be seen flowing in opposite direction to the surface layer (Fig. 8). The two high salinity cores seen in Figure $4 \mathrm{~b}$ coincide apporoximately with the depth of velocity cores at about $1750-2000 \mathrm{~m}$ and $3250-4500 \mathrm{~m}$ (Fig. 8). On the western flank of the MAR a bottom-intensified northward flow can be observed which is coincident with AABW propagation.

Net transports have been computed using the absolute velocity field for each of the 7 layers given in Table 3. The results are displayed in Figure 9. Table 4 gives layer transports and divergences for both the seasonal and annual case.

In the seasonal case the overturning cell defined as the sum of NADW and AABW transports has a strength of $17.7 \mathrm{~Sv}$ at $14.5 \mathrm{~N}$. The net geostrophic divergence in the uppermost layer (Table 4 ) is nearly compensated by an equivalent convergence in the 


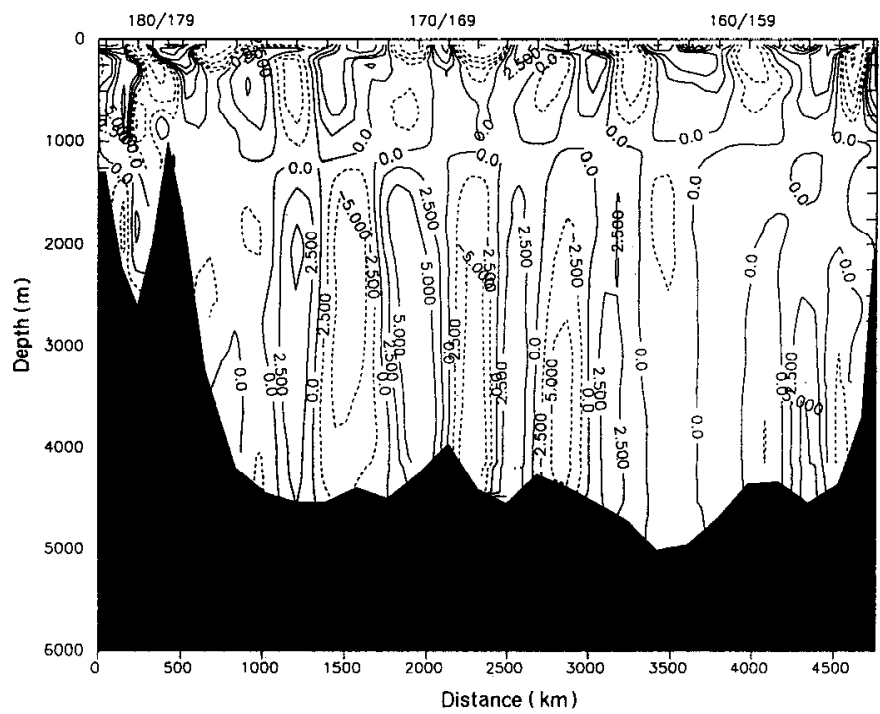

Figure 7. Vertical section of meridional velocity at $8 \mathrm{~N}$. Mass balance between a monthly mean Ekman transport and the geostrophic transport was achieved by applying the stationdependent barotropic corrections given in Figure 6. Positive velocity values are represented by solid lines and indicate transport to the north.

Ekman transport. At both latitudes, the sum of Ekman and layer 1 transport is about $15 \mathrm{~Sv}$. An additional $3 \mathrm{~Sv}$ are transported north in the depth range of NACW/SACW (layer 2). Transport within the AAIW layer (layer 3) is negligible. The compensating return flow is taking place within the Deep Water range (layers 4-6) and amounts to $18.1 \mathrm{~Sv}$.

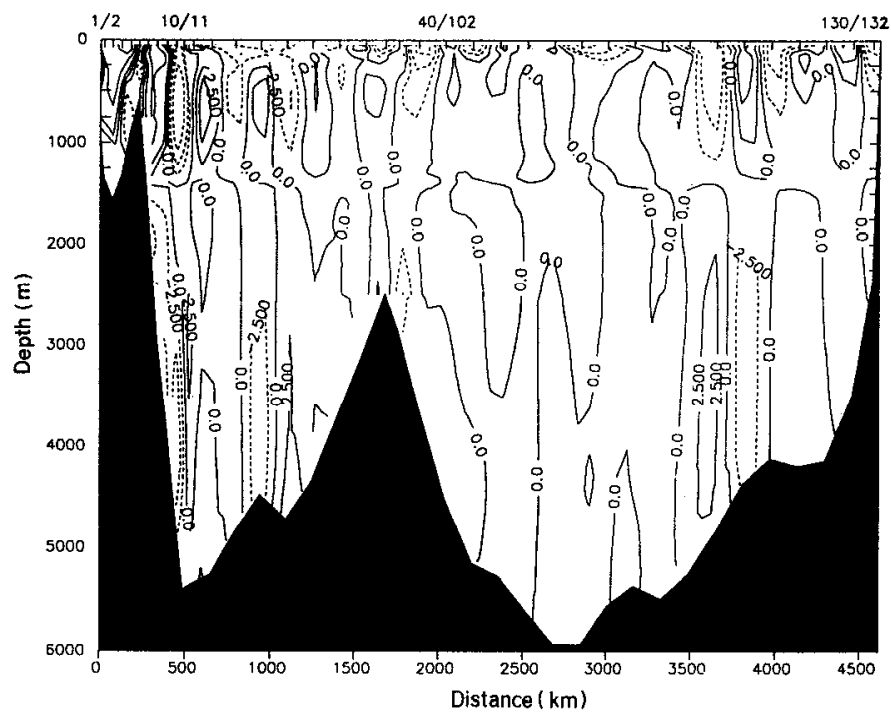

Figure 8. Same as Figure 7, except for 14.5N. 

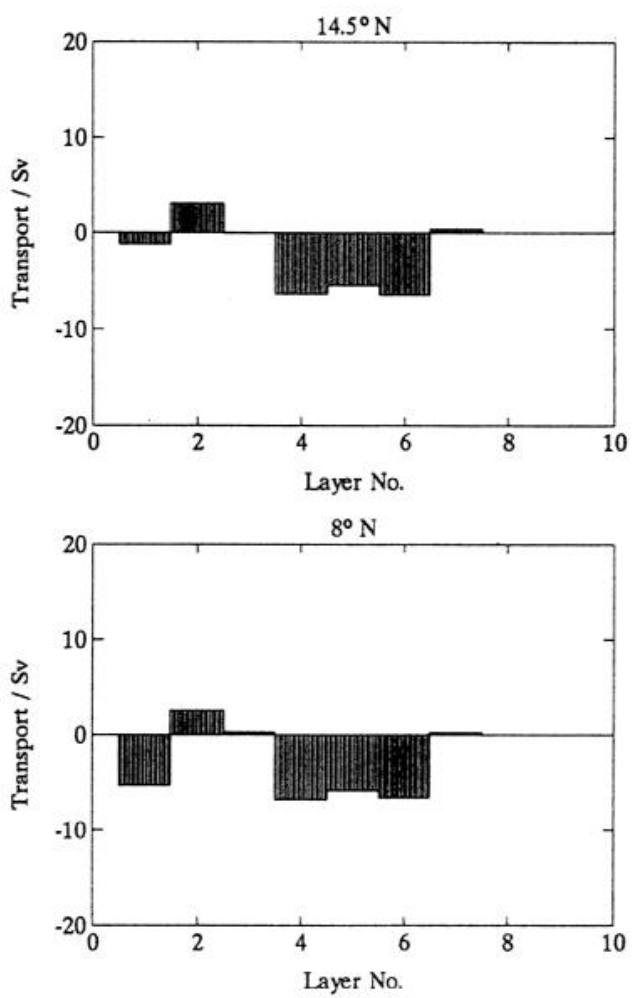

Figure 9. Volume transports in the 7 layers given in Table 3 at $8 \mathrm{~N}$ and $14.5 \mathrm{~N}$. The layer transport represent the seasonal case.

In the calculations for the annual mean the overturning cell is slightly reduced to about $15 \mathrm{~Sv}$ at $14.5 \mathrm{~N}$. In the surface layer a weaker divergence still exists which is compensated again by a convergence in the wind-driven transports. In the annual mean case (Table 4) slightly higher AAIW transports are obtained. Between 0.8 to $1.4 \mathrm{~Sv}$ are transported north through both sections. The NADW transport at $14.5 \mathrm{~N}$ amounts to $16.2 \mathrm{~Sv}$ to the south below which a small amount of $(0.3 \mathrm{~Sv})$ of northward AABW transport is estimated.

\section{The components of heat transport}

Jung (1952) and Bryan (1962) demonstrated that oceanic heat transport (HT) through a latitude circle can be approximated by:

$$
H T=\iint \rho c_{p} \theta v d x d z
$$

with $\rho=$ in-situ density, $c_{p}=$ specific heat at constant pressure, $\theta=$ potential temperature and $v=$ absolute meridional velocity. It is essential that mass is 
Table 4. Layer transports in Sv at $8 \mathrm{~N}$ and $14.5 \mathrm{~N}$ and remaining deviations from mass balance for the seasonal computations and the annual mean. Layer numbers correspond to the following water masses: (1) surface waters, (2) NACW/SACW, (3) AAIW, (4) upper NADW, (5) middle NADW, (6) lower NADW and (7) AABW.

\begin{tabular}{|c|c|c|c|c|c|c|}
\hline & \multicolumn{3}{|c|}{ Seasonal estimate } & \multicolumn{3}{c|}{ Annual mean } \\
\hline Layer no. & \multicolumn{1}{|c|}{$8 \mathrm{~N}$} & $14.5 \mathrm{~N}$ & $8 \mathrm{~N}-14.5 \mathrm{~N}$ & $8 \mathrm{~N}$ & $14.5 \mathrm{~N}$ & $8 \mathrm{~N}-14.5 \mathrm{~N}$ \\
\hline Ekman & 21.22 & 15.94 & 5.28 & 15.21 & 13.58 & 1.63 \\
\hline 1 & -5.24 & -1.18 & -4.06 & -4.34 & -1.49 & -2.85 \\
\hline 2 & 2.59 & 3.03 & -0.44 & 3.28 & 3.34 & -0.06 \\
\hline 3 & 0.31 & -0.07 & 0.38 & 1.41 & 0.73 & 0.68 \\
\hline 4 & -6.76 & -6.31 & -0.45 & -5.50 & -5.59 & -0.09 \\
\hline 5 & -5.81 & -5.42 & -0.39 & -4.41 & -4.53 & -0.12 \\
\hline 6 & -6.56 & -6.40 & 0.16 & -5.73 & -6.05 & -0.32 \\
\hline 7 & 0.27 & 0.41 & -0.14 & 0.69 & 0.31 & 0.38 \\
\hline
\end{tabular}

conserved over the integration area, so that the integral does not depend on the units of the temperature scale.

An unknown absolute velocity field represents the major difficulty in calculating oceanic heat transport directly from hydrographic observations alone. Hall and Bryden (1982) developed a method which was applied at $24 \mathrm{~N}$ and avoids the problem of determining absolute geostrophic velocities for a whole section but requires the direct transport measurements in the western boundary current. The compensating mid-ocean geostrophic transport is then given by the boundary current transport and the wind-driven transport. The only other assumptions in this approach are that the depth integrated potential temperature is uniform ovcr the section (valid at $24 \mathrm{~N}$ ) and that compensation for the Ekman transport is associated with this temperature (supported by the modelling results of Böning and Hermann, 1994). A similar argument about the compensating return flow has been used by Kraus and Levitus (1986) in their study of the annual cycle of the meridional Ekman transport. This argument might not hold everywhere. Bryden et al. (1991), investigating the subtropical Pacific, found that changes in the seasonal circulation of the Pacific were confined to the upper $700 \mathrm{~m}$.

In our approach the oceanic heat transport follows directly from the calculations of the absolute velocity field and the given potential temperature distribution. Estimating the absolute velocities through the inverse analysis automatically guarantees a zero mass balance over the integration area. We will decompose the total heat flux derived in this manner into components similar to those used by Hall and Bryden 
Table 5a. Seasonal case: Heat transport in PW ( $10^{15}$ Watt $)$ for four selected sections. Numbers for $25 \mathrm{~N}$ are from Molinari et al. (1990) and those for $11 \mathrm{~N}$ are taken from Friedrichs and Hall (1993).

\begin{tabular}{|c|l|c|c|c|c|}
\hline Section & Month & Barotropic & Baroclinic & Ekman & Total \\
\hline $8.0 \mathrm{~N}$ & May & 0.17 & -0.27 & 1.80 & 1.69 \\
\hline $11.0 \mathrm{~N}$ & March & 0.41 & -0.84 & 1.02 & 0.59 \\
\hline $14.5 \mathrm{~N}$ & Fcbruary & 0.23 & -0.04 & 1.18 & 1.37 \\
\hline $25.0 \mathrm{~N}$ & March & 1.49 & -0.50 & 0.17 & 1.16 \\
\hline
\end{tabular}

(1982) for comparison purposes. Errors in our approach are primarily related to uncertainties in the estimates of absolute velocity, as we will discuss shortly. When we decompose the heat llux, the definition of western boundary transport also becomes important.

Ekman heat fluxes were computed from Ekman volume transports multiplied by the average temperature of the Ekman layer which was assumed to have a constant depth of $50 \mathrm{~m}$. In the seasonal case we computed Ekman heat fluxes of $2.28 \mathrm{PW}$ at $8 \mathrm{~N}$ and $1.57 \mathrm{PW}$ at $14.5 \mathrm{~N}$ from the Isemar and Hasse (1985) climatology. Cumulative geostrophic heat fluxes in this case amounted to $-0.59 \mathrm{PW}$ at $8 \mathrm{~N}$ and $-0.20 \mathrm{PW}$ at $14.5 \mathrm{~N}$, producing the respective total heat transports of $1.69 \mathrm{PW}$ and $1.37 \mathrm{PW}$.

In the annual mean Ekman heat flux at $8 \mathrm{~N}$ was reduced to $1.64 \mathrm{PW}$ and to $1.34 \mathrm{PW}$ at $14.5 \mathrm{~N}$. The accompanying geostrophic heat transports were $-0.46 \mathrm{PW}$ at $8 \mathrm{~N}$ and $-0.14 \mathrm{PW}$ at $14.5 \mathrm{~N}$ giving a total of $1.18 \mathrm{PW}$ and $1.22 \mathrm{PW}$ respectively.

The total heat transports are listed in Table $5 \mathrm{a}$ and $\mathrm{b}$. They have been calculated using the absolute velocities derived from the inverse analysis. These transports were then divided afterwards into barotropic, baroclinic and Ekman heat transports as defined by Hall and Bryden (1982). The western boundary current transport corresponding to the estimates of barotropic heat flux is taken as $18 \mathrm{~Sv}$ at $14.5 \mathrm{~N}$. The compensating return flows were assumed to take place at the section-averaged

Table 5b. Annual mean: Heat transport in PW (10 15 Watt) for four selected sections. Numbers for $25 \mathrm{~N}$ are from Hall and Bryden (1982) and those for $11 \mathrm{~N}$ are taken from Friedrichs and Hall (1993).

\begin{tabular}{|c|c|c|c|c|}
\hline Section & Barotropic & Baroclinic & Ekman & Total \\
\hline $8.0 \mathrm{~N}$ & 0.15 & -0.27 & 1.30 & 1.18 \\
\hline $11.0 \mathrm{~N}$ & 1.15 & -0.84 & 0.79 & 1.11 \\
\hline $14.5 \mathrm{~N}$ & 0.23 & -0.04 & 1.03 & 1.22 \\
\hline $25.0 \mathrm{~N}$ & 1.23 & -0.43 & 0.42 & 1.22 \\
\hline
\end{tabular}


depth-integrated potential temperature which are $5.51^{\circ} \mathrm{C}$ at $8 \mathrm{~N}$ and $5.99^{\circ} \mathrm{C}$ at $14.5 \mathrm{~N}$. The results of Hall and Bryden (1982) from the subtropical Atlantic at $25 \mathrm{~N}$ have been included in the table in order to compare the respective components between the tropical and the subtropical Atlantic. The estimate of Molinari et al. (1990) at $25 \mathrm{~N}$ in Table $5 \mathrm{a}$ represents the climatological month of March, while the annual mean (Hall and Bryden, 1982) is given in Table 5b. Values for the section at $11 \mathrm{~N}$ are taken from Friedrichs and Hall (1993) and represent an estimate for a climatological March in Table $5 a$ and the annual mean in Table $5 b$.

The seasonal heat transport estimate at $8 \mathrm{~N}, 1.69 \mathrm{PW}$, (Table 5a) is nearly identical with an earlier estimate of $1.61 \mathrm{PW}$ made by Roemmich (1983) using a combination of IGY-sections. The difference mainly results from the use of the Isemer-Haase (1985) climatology with higher Ekman transports compared to the HellermanRosenstein (1983) climatology used by Roemmich (1983). It agrees in magnitude very well with the monthly budgets of Hsiung et al. (1989). Their analysis of net surface heat fluxes and heat storage gives a maximum heat transport of $1.5 \mathrm{PW}$ during May in the tropical band between 5-10N. Wunsch (1984), however, calculated upper and lower bounds for oceanic heat transport in the Atlantic. Compared to these bounds the heat transport estimate at $14.5 \mathrm{~N}$ is in the upper range while the value at $8 \mathrm{~N}$, like the prior estimate of Roemmich (1983) lies above the upper bound. However, these bounds had been calculated with the constraint that the heat transport reaches its maximum between $25-30 \mathrm{~N}$, while more recent model runs (Sarmiento, 1986) indicate a maximum of the heat transport at about $10 \mathrm{~N}$.

A significant shift in the dominant term from the subtropical sections at $25 \mathrm{~N}$ to the tropical sections at 8 and $14.5 \mathrm{~N}$ is evident in Table $5 \mathrm{a}$. At $25 \mathrm{~N}$ the barotropic transport associated with the boundary current is the dominant term, while the Ekman transport dominates in both tropical sections. The barotropic heat transport increases to the north.

The baroclinic heat transport reaches a minimum at $14.5 \mathrm{~N}$ being nearly indistinguishable from zero at this latitude. Higher baroclinic transports exist to the north and south. Model results from Sarmiento (1986) give a minimum of baroclinic heat transport in the tropical ocean, but centered at $10 \mathrm{~N}$. In our calculations this term is particularly noisy in the eastern basin changing sign between station pairs everywhere and it cannot be excluded that this term might be affected by the horizontal resolution of the section and the lack of stations on the African shelf.

In the annual case very little variation in total heat transport can be found between $25 \mathrm{~N}$ and $8 \mathrm{~N}$ (Table $5 \mathrm{~b}$ ) with amplitudes ranging between 1.18 and 1.22 PW. Model simulations (Sarmiento, 1986) have indicated such a broad maximum of heat transport although they are lower in magnitude. For the tropical sections at 8 and $14.5 \mathrm{~N}$ the Ekman transport remains the largest contributor. The $11 \mathrm{~N}$ section is somewhat peculiar as it shows a large barotropic heat transport component in the annual mean. This is partly due to the definition of the boundary current. Friedrichs and Hall 


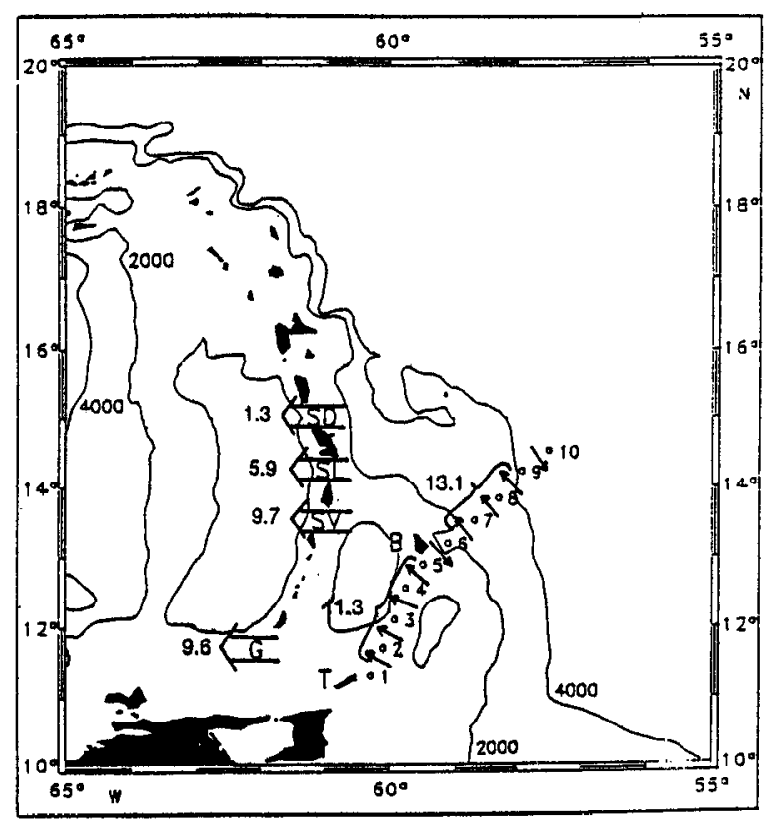

Figure 10. Schematic representation of boundary transports between $10 \mathrm{~N}$ and $16 \mathrm{~N}$. Transport through the passages between the Lesser Antilles has been taken from Stalcup and Metcalf (1972).

(1993) define the boundary current to be confined over the shelf to depth less than $200 \mathrm{~m}$ and include the deeper parts into the geostrophic component. They also argue that all the annual variation in transport is associated with the shallowest part of the NBC over the shelf. The resulting large amplitude in the shallow water and the high temperatures are then causing the large barotropic component.

\section{Errors in heat flux estimates}

Errors in heat transport estimates arise from various sources. A small error results from the amount of water which is supplied to the Polar Sea and Atlantic through the Bering Strait. The heat transport associated with the $1.5 \mathrm{~Sv}$ transport through the Strait is only $-0.03 \mathrm{PW}$ since temperatures are low (Hall and Bryden, 1982).

Eddies are a further source of errors. They are not well resolved in the sections with a spacing of $150 \mathrm{~km}$ between deep stations. As described by Hall and Bryden (1982) this error can be estimated by computing the deviation of the baroclinic transport from its zonal mean. The resulting eddy fluxes are $0.05 \mathrm{PW}$ at $8 \mathrm{~N}$ and $0.03 \mathrm{PW}$ at $14.5 \mathrm{~N}$. An alternative way of calculating the errors associated with the eddy heat transport is applied at $14.5 \mathrm{~N}$. At this section shallow measurements $(2000 \mathrm{~m})$ alternated with measurements to the bottom (i.e. above $2000 \mathrm{~m}$ station spacing was $75 \mathrm{~km}$ ). The horizontal resolution could thus be increased by including 
these shallow measurements in the heat transport calculation assuming an invariant deep temperature structure. Differences between both estimates were attributed to the effect of eddy heat transport. The calculated difference is $0.02 \mathrm{PW}$, in close agreement with the above estimate. It can therefore be concluded that the eddy heat transport does not play a major role at these latitudes, similar to $25 \mathrm{~N}$.

Another source of error arises from the fact that no direct current measurements were available in the western boundary current. This may result in an inaccurate estimate of the barotropic component in this current. Although our comparison with other hydrographic measurements and direct current observations shows surprising good agreement, we still attribute a major source of error to this term because of the high variability in the boundary current region. To set an upper bound to these uncertainties we assume that errors in the boundary current transport amount to $10 \mathrm{~Sv}$. Changing the barotropic boundary current signal by $10 \mathrm{~Sv}$ must be accompanied by an equivalent but opposite change in the ocean interior in order to satisfy the mass balance. The only way that this uncertainty is going to affect the heat transport calculations is through the fact that the depth-averaged potential temperatures in the boundary current are higher than in the ocean interior. The error in heat transport estimates is therefore associated with the difference between depthaveraged temperatures in the boundary current and in the interior. At $8 \mathrm{~N}$ the depth-integrated temperatures in the boundary current deviated by $2.5^{\circ} \mathrm{C}$ from the zonal average, yielding an error $0.09 \mathrm{PW}$ in the heat transport. At $14.5 \mathrm{~N}$ the depth-integrated temperatures differed by $3.5^{\circ} \mathrm{C}$ from the zonal mean, with a respective error in heat transport of $0.13 \mathrm{PW}$.

Assuming an uncertainty of $2 \mathrm{~Sv}$ in Ekman transports the associated errors in heat transport are $0.15 \mathrm{PW}$ at $8 \mathrm{~N}$ and $0.13 \mathrm{PW}$ at $14.5 \mathrm{~N}$. Finally both sections have gaps without measurements near the African coast. At $8 \mathrm{~N}$ the gap is nearly $200 \mathrm{~km}$ wide while it is only $50 \mathrm{~km}$ wide at $14.5 \mathrm{~N}$. The unresolved transport is calculated by taking the next available station pair transport as a reference, resulting in a error of $0.2 \mathrm{PW}$ at $8 \mathrm{~N}$ and only $0.1 \mathrm{PW}$ at $14.5 \mathrm{~N}$. These estimates appear reasonable since they match the average station pair heat transport of stations outside the boundary current regime. The total error at $8 \mathrm{~N}$ is estimated as $\pm 0.52 \mathrm{PW}$, and $\pm 0.42 \mathrm{PW}$ at $14.5 \mathrm{~N}$.

\section{Comparison with volume and heat flux estimates through an $11 \mathrm{~N}$ section}

Approximately one month after the $14.5 \mathrm{~N}$ section was started, a similar survey was conducted in March along 11N (Friedrichs and Hall, 1993). Although the sections were separated in space by only $390 \mathrm{~km}$ and in timc by onc month they show differences as well as similarities in the flow field.

There are large differences in the horizontal structure and strength of the upper layer circulation fields between the three cruises that are best represented in the cumulative layer transports (Fig. 11a-g) and similar plots in Friedrichs and Hall 

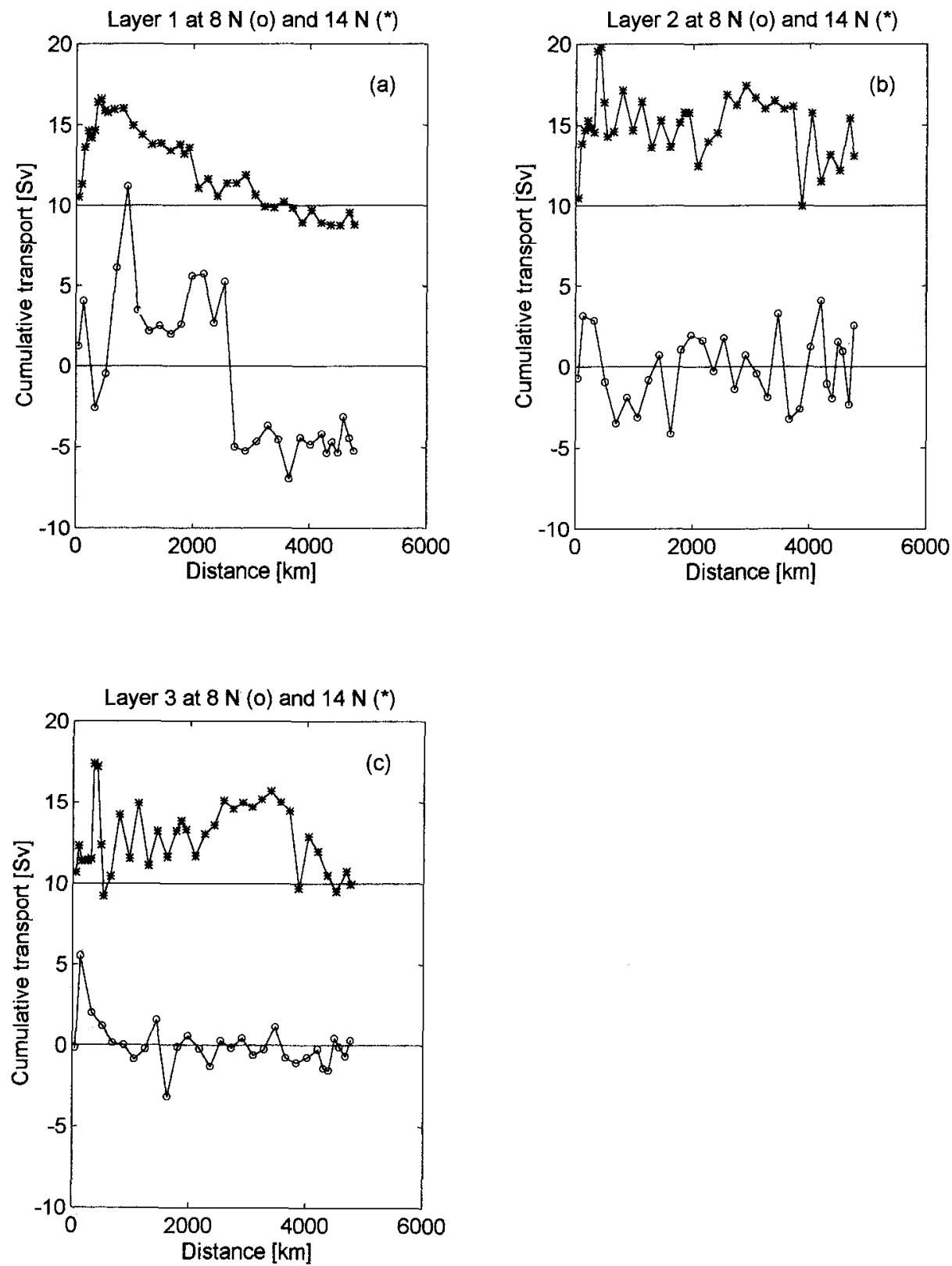

Figure 11. Cumulative layer transports along $8 \mathrm{~N}$ and $14.5 \mathrm{~N}$ for Surface Waters (a), Central Waters (b), AAIW (c), uNADW (d), mNADW (e), INADW (f) and AABW (g). For definition of the layers see Table 3. The layer transports at $14.5 \mathrm{~N}$ have been offset from respective transports at $8 \mathrm{~N}$ by $10 \mathrm{~Sv}$ for layer 1 to $3,15 \mathrm{~Sv}$ for layers $4-6$ and $5 \mathrm{~Sv}$ for layer 7 . 

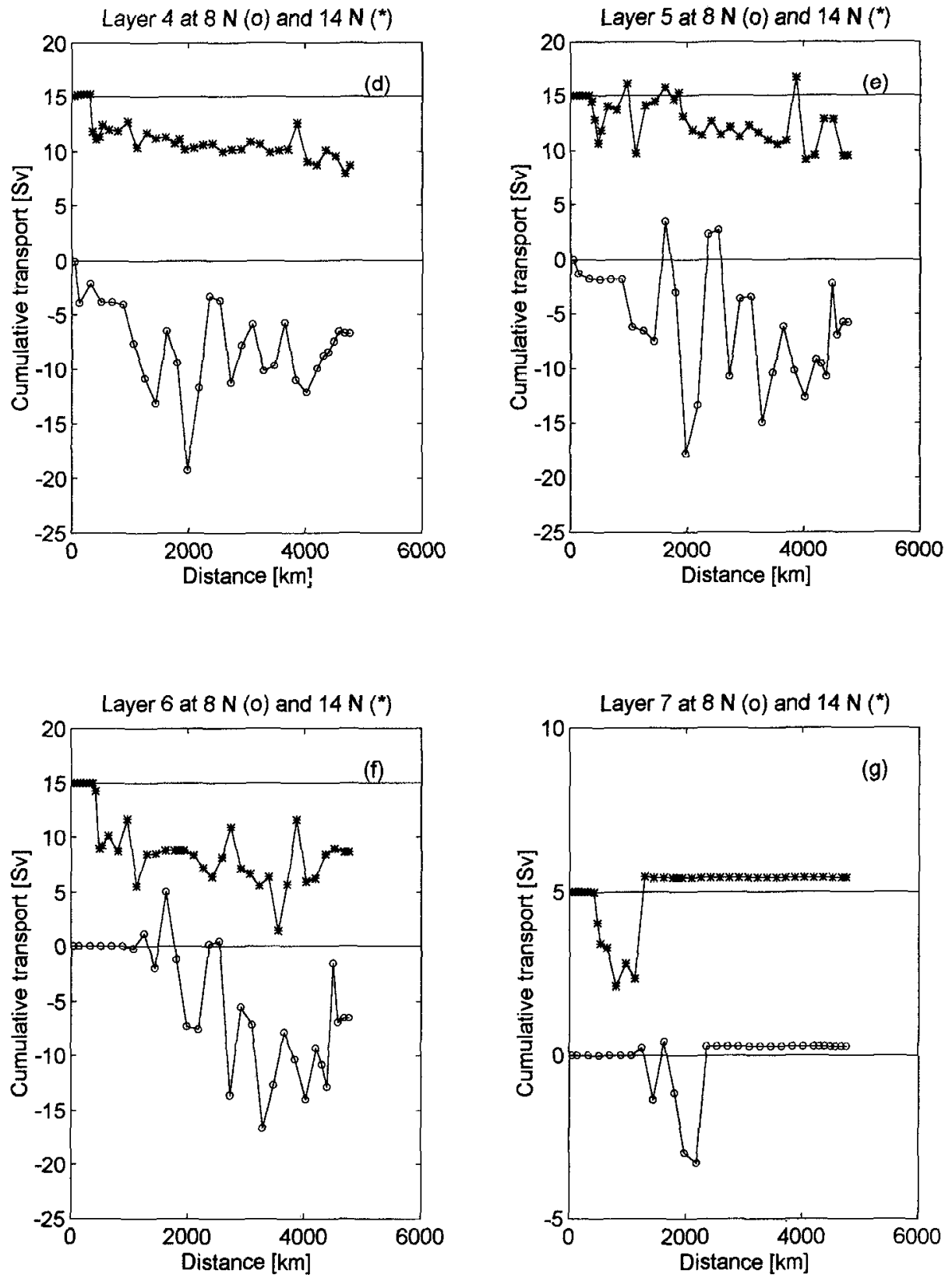

Figure 11. (Continued)

(1993), their Figure 8. The major difference between the sections appears to be in the location and strength of a recirculation within the western boundary.

The basic feature dominating the upper layer transports at $11 \mathrm{~N}$ is a strong recirculation taking place just offshore of the northward transport within the western 


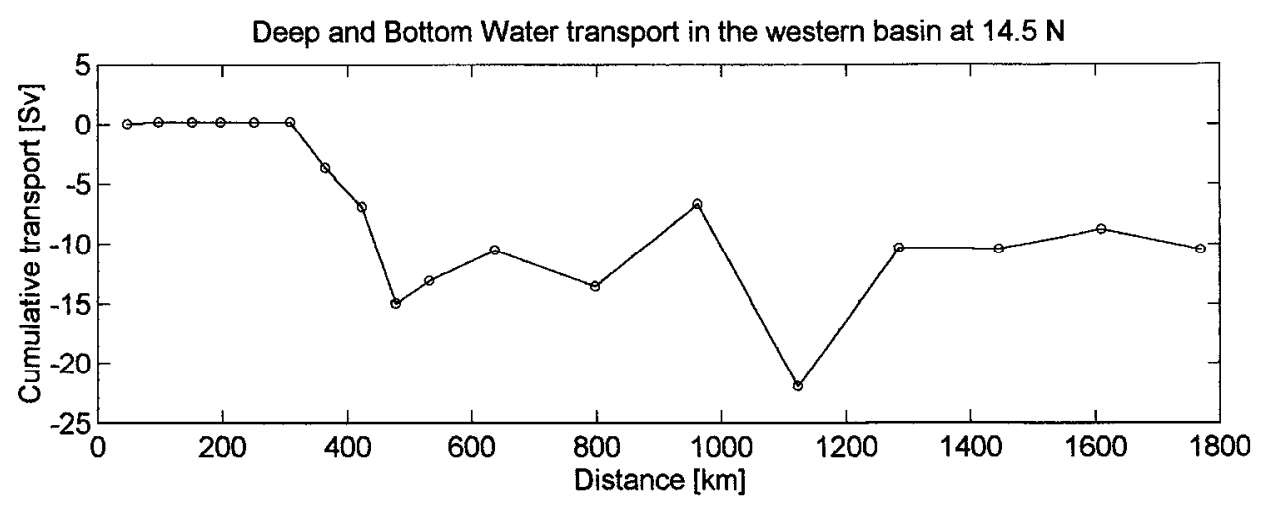

Figure 12. Cumulative transport of Deep and Bottom Water within the western basin at $14.5 \mathrm{~N}$.

boundary (i.e., within $500 \mathrm{~km}$ of the western boundary). A similar narrow recirculation is not observed on either the $8 \mathrm{~N}$ or $14.5 \mathrm{~N}$ transects (Figs. 11a and b). Thus although the estimates of total northward upper layer boundary transport are similar; $7.2 \mathrm{~Sv}$ at $8 \mathrm{~N}, 11.3 \mathrm{~Sv}$ at $14.5 \mathrm{~N}$ and $11.8 \mathrm{~Sv}$ at $11 \mathrm{~N}$, net transports in the western basin are dramatically different; $7.3 \mathrm{~Sv}$ at $8 \mathrm{~N}, 8.9 \mathrm{~Sv}$ at $14.5 \mathrm{~N}$ and $-0.2 \mathrm{~Sv}$ at $11 \mathrm{~N}$. Friedrichs and Hall (1993) explain the large recirculation in the western basin through the unusual persistence of the NECC and associated eastward motion (Katz, 1993).

Within the AAIW layer (layer 3, Fig. 11c), there is considerable eddy activity in the western basin at $11 \mathrm{~N}$ and $14.5 \mathrm{~N}$. The eddies make it difficult to define unambiguously if the AAIW recirculates in the basin. At $8 \mathrm{~N}$, all of the AAIW transport recirculates within a well defined gyre. All three sections show little eddy activity in the eastern basin within this layer. At 11 and $14.5 \mathrm{~N}$, the flow east of the MAR is in general northward, except within $1000 \mathrm{~km}$ of the eastern boundary at $14.5 \mathrm{~N}$, where the flow is southward. The absolute magnitude of the AAIW transport is still controversial. Richardson and Schmitz (1993) calculated a transport of 5.8 Sv when integrating float velocities to approximately $450 \mathrm{~km}$ offshore. Computations for $11 \mathrm{~N}$ and $14.5 \mathrm{~N}$ both show a maximum in cumulative transport of about $7 \mathrm{~Sv}$ near the western boundary (Fig. 11c) agreeing well with the direct transport estimate.

Although the maximum southward flow in the NADW layers is similar in both sections, $26.5 \mathrm{~Sv}$ at $11 \mathrm{~N}$ and $22.5 \mathrm{~Sv}$ at $14.5 \mathrm{~N}$, the horizontal structure of the deep flow is somewhat different. At $11 \mathrm{~N}$, two limbs of southward flow are observed for water with temperatures below $4.7^{\circ} \mathrm{C}$, approximately $20 \mathrm{~Sv}$ is within $400 \mathrm{~km}$ of the boundary and another $6.5 \mathrm{~Sv}$ between 500 and $800 \mathrm{~km}$ from the boundary (Friedrichs and Hall, 1993, Fig. 9). At $14.5 \mathrm{~N}$, approximately $16 \mathrm{~Sv}$ is within $400 \mathrm{~km}$ of the boundary and another $6.5 \mathrm{~Sv}$ flows southward at about $1000 \mathrm{~km}$ (Fig. 12). At $14.5 \mathrm{~N}$, approximately $20 \mathrm{~Sv}$ of the deep flow recirculates back north in the western boundary 
for a net throughflow of only $6 \mathrm{~Sv}$. At $11 \mathrm{~N}$, approximately $13 \mathrm{~Sv}$ recirculates back to the north in the western basin for a net throughflow of $13 \mathrm{~Sv}$.

The circulation pattern in the decpest layer (AABW) looks very similar at 11 and $14.5 \mathrm{~N}$ indicating a closed circulation cell of about $2.5-3 \mathrm{~Sv}$ in the western basin. Net transport at 8 and $14.5 \mathrm{~N}$ is small (order of magnitude: $0.5 \mathrm{~Sv}$ ), since none of the specified water type $\left(\sigma_{4}>45.9\right)$ is encountered in the eastern basin. Friedrichs and Hall (1993) using a different definition of AABW $\left(\theta<1.8^{\circ} \mathrm{C}\right)$, compute a net transport of $2.1 \mathrm{~Sv}$ across the $11 \mathrm{~N}$ section which depends completely on the northward motion within the eastern basin. They claim that the source of this water has to be the Vema Fracture Zone since within the eastern basin no major connection to the southern Atlantic exists at this depth range.

\section{Conclusions}

Absolute velocity calculations at $14.5 \mathrm{~N}$ show a northward boundary current in the upper thermocline that is divided into a branch over the shallow shelf and a second branch at the shelf break. A similar picture emerges at $8 \mathrm{~N}$. Only the branch over the shelf break at $14.5 \mathrm{~N}$ transports SUW with maximum salinities of 37.2 and was probably connected to the NEC. Northward transport of thermocline waters including the AAIW amounts to $11.3 \mathrm{~Sv}$ in the shallow part of the water $(H<1000 \mathrm{~m})$ and 13.2 Sv in the branch over the shelf break. This northward flow is feeding the inflow into the Caribbean through passages within the Lesser $\Lambda$ ntilles.

Our transport calculations give a magnitude of the western boundary current of about $24.5 \mathrm{~Sv}$. (This is an upper bound since it ignores the counterflow between the two northward branches.) Direct current measurements in the passages between the Lesser Antilles provide a check for these transport estimates. Two month-long current measurements in the four major passages through the Lesser Antilles, carried out by Stalcup and Metcalf (1972), resulted in a westward transport of $26.5 \mathrm{~Sv}$ of water entering from the Atlantic. The transport components through the Grenada, St. Vincent, St. Lucia and St. Dominica passages were 9.6, 9.7, 5.9 and $1.3 \mathrm{~Sv}$, respectively. The $T / S$ properties of the two western boundary current branches differ considerably. Within the branch over the shelf the salinity maximum is below 36.5 while the branch over the shelf break transports SUW with a maximum salinity of 37.2. This branch must have its origin in the North Equatorial Current (NEC). A schematic of the flow is presented in Figure 10. It can be confirmed from $T / S$ relationships that water masses from both branches enter the Caribbean through the four passages between the Lesser Antilles, with SUW being observed in the northern two passages only.

The near bottom flow at $14.5 \mathrm{~N}$ shows influences of colder and fresher AABW in the eastern basin than to the north and south with potential temperatures less than $1.75^{\circ} \mathrm{C}$ and salinities less than 34.868 . The diluted form of AABW has entered the basin through the Vema Fracture Zone. As described by McCartney et al. (1991) 
most of it flows east in a very narrow tongue. The low values observed at $14.5 \mathrm{~N}$ must be part of a northward flowing branch of AABW. The measurements indicate that a tongue of water with temperatures less than $1.75^{\circ} \mathrm{C}$ extends north from the sill exit of the Vema Fracture Zone to at least 14.5N.

The tropical ocean is dominated by large seasonal fluctuations associated with changes in the wind field. This variability has to be considered in the interpretation of volume and heat transport estimates. A comparison with climatological wind data (Isemer and Hasse, 1985) showed that the measurements at $14.5 \mathrm{~N}$ represented a typical period in the seasonal cycle. The seasonal meridional overturning cell had a strength of $17.7 \mathrm{~Sv}$, and we calculated a heat transport estimate of $1.37 \pm 0.42 \mathrm{PW}$. However, Friedrichs and Hall (1993) obtained a heat transport value of only 0.3 to $0.59 \mathrm{PW}$ at $11 \mathrm{~N}$ a month later. Part of this change seems to be connected to fluctuations in the wind field. While the trade winds were strong and steady along $14.5 \mathrm{~N}$ during February they were extremely weak a month later along $11 \mathrm{~N}$. The uncharacteristically low wind stress values were confined to the eastern basin (Cherekin and Roemmich, 1991). Over an area of about $1000 \mathrm{~km}$ offshore the African coast the wind stresses were close to zero. As a result the Ekman transport along $11 \mathrm{~N}$ calculated from the observed winds amounts only to $9.1 \mathrm{~Sv}$ compared to $15.9 \mathrm{~Sv}$ along $14.5 \mathrm{~N}$.

Since the heat transport in the tropical ocean is dominated by the wind-driven component estimates of heat transport are affected strongly by the choice of Ekman transport. We thus presented as seasonal estimates of heat transport as well as annual means and decomposed these into components defined by Hall and Bryden (1982). The wind-driven component is the largest contributor to the heat transport in the tropics $(8,14.5 \mathrm{~N})$ in both situations. While the barotropic component is largest at $25 \mathrm{~N}$. This not only due to the fact that the magnitude of the boundary current increases to the north from $17-22 \mathrm{~Sv}$ at $8 \mathrm{~N}$ to $30 \mathrm{~Sv}$ in the Florida Straits. It is also due to the fact that the water transported north by the Gulf Stream is considerably warmer than the NBC waters. Almost all of the transport in the Straits of Florida is achieved at temperatures above $9.5^{\circ} \mathrm{C}$ only a negligible amount (less $1 \mathrm{~Sv}$ ) is found at temperatures between $9.5-7^{\circ} \mathrm{C}$ which is the lowest temperature class observed (Leaman et al., 1989). Hall and Bryden give an average potential temperature for the boundary current of $15.6^{\circ} \mathrm{C}$ which is more than $10^{\circ} \mathrm{C}$ warmer than the section average. Temperatures in the $\mathrm{NBC}$ at $14.5 \mathrm{~N}$ are much lower. At depth greater than $500 \mathrm{~m}$ (cf. Fig. 4a) temperatures drop below $10^{\circ} \mathrm{C}$ even over the shallow shelf and nearly reach $5^{\circ} \mathrm{C}$ at the bottom. This is the influence of waters of South Atlantic origin which are transported north by the NBC. As a result the potential temperature of the boundary current region (Sts. $1-8$ ) is $9.36^{\circ} \mathrm{C}$ which is only $3.4^{\circ} \mathrm{C}$ higher than the section average. At $8 \mathrm{~N}$ the averaged potential temperature of the boundary current (Sts. $184-177$ ) is only $2.5^{\circ} \mathrm{C}$ warmer than the section average and amounts to $7.98^{\circ} \mathrm{C}$. The definition of the boundary current at $8 \mathrm{~N}$ and $14.5 \mathrm{~N}$ is not as obvious as in the 
Florida Straits where it is confined by topography. We used the velocity sections (cf. Figs. 7 and 8) and defined the boundary current as the region of strong northward flow with the station limits as given above.

The high variability in the wind-driven transport and its dominance in the heat transport budget are only one reason why the seasonal heat transport estimate for $11 \mathrm{~N}$ by Friedrichs and Hall differs considerably from the others in Table 5a. Examination of transports in water mass layers shows differences in strength and position of circulation patterns in almost all layers. Thus part of the differences in heat transport estimates are caused by these changes in baroclinic structure. This can also be seen from the fact that heat transport calculations using a climatological monthly value only raises the estimate to $0.59 \mathrm{PW}$.

In the annual mean a broad maximum of heat transport emerges between 8 and $25 \mathrm{~N}$ with amplitudes of about 1.2 PW. Model results have indicated such a structure but had not been able so far to give precise magnitudes of heat transport.

Acknowledgments. The coordinated field program was carried out by the Marine Physics Department of the Institut für Meereskunde, Kiel University, Germany, and the NOAA/ AOML, Miami, USA. The joint analysis was facilitated by CIMAS, University of Miami and NOAA, hosting the fourth author as a visiting investigator. The assistance of the hosting institution's staff is much appreciated. We have benefitted in the analysis from discussions with N. Zangenberg, M. Hall and M. McCartney. We would also like to thank Elizabeth Jones for her valuable comments and support in creating this manuscript. Funding for this work was provided by the Deutsche Forschungsgemeinschaft (SFB 133). We benefitted also from valuable comments of the two reviewers.

\section{REFERENCES}

Bauer, E. and G. Siedler. 1988. The relative contributions of advection and isopycnal and diapycnal mixing below the subtropical salinity maximum. Deep-Sea Res., 35, 811-837.

Böning, C. W. and P. Herrman. 1994. Annual cycle of poleward heat transport in the ocean: Results from high-resolution modeling of the North and Equatorial Atlantic. J. Phys. Oceanogr., 24, 91-107.

Bryan, K. 1962. Measurements of meridional heat transport by ocean currents. J. Geophys. Res., 67, 3403-3414.

Bryden, H. L. and M. M. Hall. 1980. Heat transport by ocean currents across $25 \mathrm{~N}$ latitude in the Atlantic Ocean. Science, 207, 884-886.

Bryden, H. L., D. Roemmich and J. A. Church. 1991. Ocean heat transport across $24 \mathrm{~N}$ in the Pacific. Deep-Sea Res., 38, 297-324.

Chereskin, T. K. and D. Roemmich. 1991. A comparison of measured and wind-derived Ekman transport at $11 \mathrm{~N}$ in the Atlantic Ocean. J. Phys. Oceanogr., 21, 869-878.

Defant, A. 1936. Schichtung und Zirkulation des Atlantischen Ozeans. Die Troposphäre. Wiss. Ergebn. Dt. Atlant. Exped. "Meteor" 1925-1927, Band VI, 1. Teil, 289-411.

Fine, R. A. and R. L. Molinari. 1988. A continuous deep western boundary current between Abaco (26.5N) and Barbados (13N). Deep-Sea Res., 35, 1441-1450.

Friedrichs, Marjorie A. M. and M. M. Hall. 1993. Deep circulation in the tropical Atlantic. J. Mar. Res., 51, 697-736. 
Fuglister, F. C. 1960. Atlantic Ocean atlas of temperature and salinity, profiles and data from the International Geophysical Year 1957-1958, Vol. 1, Woods Hole Oceanographic Institution, Woods Hole, MA.

Hall, M. M. and H. L. Bryden. 1982. Direct estimates and mechanisms of ocean heat transport. Deep-Sea Res., 29, 339-359.

Hellermann, S. and M. Rosenstein. 1983. Normal monthly windstress over the World Ocean with error estimates. J. Phys. Oceanogr., 13, 1093-1104.

Hsiung, J., R. E. Newell and T. Houghtby. 1989. The annual cycle of oceanic heat storage and oceanic meridional heat transport. Quart. J. Roy. Met. Soc., 15, 1-28.

Isemer, H.-J. and L. Hasse. 1985. The Bunker Climate Atlas of the North Atlantic Ocean, 2, Air-Sea Interactions, Springer Verlag, Berlin, $252 \mathrm{pp}$.

Jenkins, W. J. and P. B. Rhines. 1980. Tritium in the deep North Atlantic Ocean, Nature, 286, $877-880$.

Jung, G. H. 1952. Note on the meridional transport of energy by the oceans. J. Mar. Res., 11, 139-146.

Katz, E. J. 1993. An interannual study of the North Equatorial Countercurrent. J. Phys. Oceanogr., 23, 116-123.

Klein, B. 1992. Die Kapverden-Frontalzone, Berichte Inst. f. Meereskunde, Kiel, 227, 189 pp.

Kraus, E. B. and S. Levitus. 1986. Annual heat flux variations across the tropical circles. J. Phys. Oceanogr., 16, 1479-1486.

Leaman, K. D., E. Johns and T. Rossby. 1989. The average distribution of volume transport and potential vorticity with temperature at three sections across the Gulf Stream. J. Phys. Oceanogr., 19, 36-51.

Mantyla, A. W. 1987. Standard seawater comparisons update. J. Phys. Oceanogr., 17, 543-548.

McCartney, M. S., S. L. Bennett and M. E. Woodgate-Johns. 1991. Eastward flow through the mid-Atlantic Ridge at $11 \mathrm{~N}$ and its influence on the abyss of the Eastern basin. J. Phys. Oceanogr., 21, 1089-1121.

Molinari, R. L., R. A. Fine and E. Johns. 1992. The Deep Western Boundary Current in the tropical North Atlantic Ocean. Deep-Sea Res., 39, 1967-1984.

Molinari, R. L., E. Johns and J. F. Festa. 1990. The annual cycle of meridional heat flux in the Atlantic Ocean at 26.5N. J. Phys. Oceanogr., 20, 476-482.

Pickart, R. S. 1992. Water mass components of the North Atlantic Deep Western Boundary Current. Deep-Sea Res., 39, 1553-1572.

Richardson, P. L. and W. J. Schmitz. 1993. Deep cross-equatorial flow in the Atlantic measured with SOFAR floats. J. Geophys. Res., 98, 8371-8388.

Roemmich, D. 1983. The balance of geostrophic and Ekman transport in the tropical Atlantic Ocean. J. Phys. Oceanogr., 11, 1534-1539.

Roemmich, D. and C. Wunsch. 1985. Two transatlantic sections: meridional circulation and heat flux in the subtropical North Atlantic Ocean. Deep-Sea Res., 32, 619-644.

Sarmiento, J. L. 1986. On the North and Tropical Atlantic heat balance. J. Geophys. Res., 91, 11677-11689.

Saunders, P. M. 1986. The accuracy of measurements of salinity, oxygen and temperature in the deep ocean. J. Phys. Oceanogr., 16, 189-195.

Stalcup, M. C. and W. G. Metcalf. 1972. Current measurements in the passages of the Lesser Antilles. J. Geophys. Res., 77, 1032-1049.

Warren, B. A. 1973. Transpacific hydrographic sections at latitudes $43 \mathrm{~N}$ and 28S: The SCORPIO Expedition-II. Deep Water. Deep-Sea Res., 20, 9-38. 
Wilburn, A. M., E. Johns and M. Bushnell. 1990. Current velocity and hydrographic observations in the southwestern North Atlantic Ocean: Subtropical Atlantic Climate Studies (STACS), 1989, NOAA Data Report ERL AOML-18, 97 pp.

Worthington, V. 1976. On the North Atlantic Circulation, John Hopkins Oceanographic Studies, 6, $101 \mathrm{pp}$.

Wunsch, C. 1984. An eclectic Atlantic Ocean circulation model. Part I: The meridional flux of heat. J. Phys. Oceanogr., 14, 1712-1733.

Wüst, G. 1936. Schichtung und Zirkulation des Atantischen Ozeans. Das Bodenwasser und die Gliederung der Atlantischen Tiefsee. Wiss. Ergebn. Dt. Atlant. Exped. "Meteor" 1925-1927, Band VI, 1.Teil, 3-107.

Received: 1 August, 1994; revised: 12 July, 1995. 